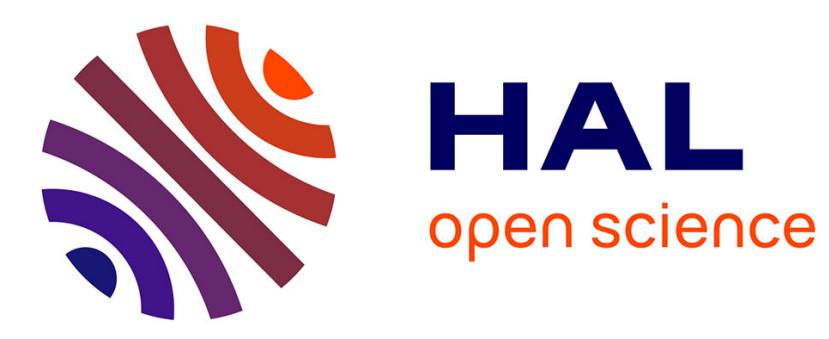

\title{
Product diversification and bank performance: does ownership structure matter?
}

Nadia Saghi-Zedek

\section{To cite this version:}

Nadia Saghi-Zedek. Product diversification and bank performance: does ownership structure matter?. Journal of Banking and Finance, 2016, 71, pp.154-167. 10.1016/j.jbankfin.2016.05.003 . halshs01342528

\section{HAL Id: halshs-01342528 \\ https://shs.hal.science/halshs-01342528}

Submitted on 11 Jul 2016

HAL is a multi-disciplinary open access archive for the deposit and dissemination of scientific research documents, whether they are published or not. The documents may come from teaching and research institutions in France or abroad, or from public or private research centers.
L'archive ouverte pluridisciplinaire HAL, est destinée au dépôt et à la diffusion de documents scientifiques de niveau recherche, publiés ou non, émanant des établissements d'enseignement et de recherche français ou étrangers, des laboratoires publics ou privés. 
Product diversification and bank performance: does ownership structure matter?

\author{
Nadia Saghi-Zedek \\ Graduate School of Management (IGR), Université de Rennes 1, CREM UMR CNRS 6211,
} 11 rue Jean Macé, 35708 Rennes, France *

\begin{abstract}
Using detailed data on control chains of 710 European commercial banks, we test whether the presence of some categories of controlling shareholders affects product diversification performance. We find that when banks have no controlling shareholder or have only family and state shareholders activity diversification yields diseconomies. However, as long as the control chain involves banking institutions, institutional investors, industrial companies or any other combination of these shareholder categories, banks benefit from diversification economies: they display higher profitability, lower earnings volatility and lower default risk. This is potentially because such categories of shareholders bring additional skills to manage diverse activities. A further exploration shows that such mitigating roles are greater for domestic and diversified shareholders. Our findings provide insights on why banks suffer from greater activity diversification and have several policy implications.
\end{abstract}

JEL Classification: G21, G28

Keywords: ownership structure, product diversification, performance, European banking

* Parts of this research were done when the author was an assistant professor at the University of Limoges (LAPE EA 1088). We are grateful to the editor, two anonymous referees, Jean-Bernard Chatelain, Simon Cornee, Robert DeYoung, Jessica Fouilloux, Iftekhar Hasan, Kose John, Laetitia Lepetit, Franck Moraux, Patrick Navatte, Alain Sauviat, Amine Tarazi and Jean-Laurent Viviani for their helpful comments on earlier versions of the paper. We also thank the participants of the $30^{\text {th }}$ International Symposium on Money, Banking and Finance; the $5^{\text {th }}$ International Conference of the Financial Engineering and Banking Society; the $32^{\text {nd }}$ International Conference of the French Finance Association; the Journée Bretonne de Recherche; and those of the University of Rennes 1 Finance Seminar for their valuable suggestions. All errors remain our responsibility.

\footnotetext{
* Corresponding author: nadia.saghi@univ-rennes1.fr (N. Saghi-Zedek), Tel: +3323235091.
} 


\section{Introduction}

The question of whether policy makers should restrict banking activities or allow banks to engage in diverse activities is still a debatable policy issue. Although the effect of greater activity diversification (i.e., a combination of traditional and nontraditional activities) on banks' performance (profitability and risk) is well addressed in the literature, there is no consensus thus far, with evidence showing the presence of economies and diseconomies of diversification. These inconclusive findings cry out for a further investigation to learn why banks suffer or benefit from their diversification strategy. The objective of this paper is therefore to test whether diversification performance depends on the bank's organizational aspect, and especially its ownership structure. More specifically, we test whether banks involving in their ownership structures shareholders with prior experience in managing a variety of activities are better able to reap benefits of activity diversification.

In some countries -such as in Europe- banks and firms are not stand-alone but, rather, they belong to a group of firms linked via strong shareholding relationships. In such ownership settings, a shareholder achieves the control of a specific bank through a large number of intermediate corporations: a shareholder directly controls a firm, which in turn controls another firm, which might itself control another firm, and so forth. ${ }^{1}$ Within these multilayer ownership structures, several shareholders of different categories are involved in the bank's decision making: banking institutions, institutional investors (mutual funds, financial companies and insurance companies), industrial companies, families and so forth. This set of shareholders could actually provide the bank an initial exposure and background and therefore sufficient ability and expertise to easily diversify. For instance, institutional investors are known to have prior experience in loans syndication (Lim et al., 2014), securities and insurance underwriting, brokerage and mutual fund activities and, as a consequence, they are able to deliver additional skills and expertise allowing the bank to reap benefits accruing from activity diversification.

More precisely, in this paper we assume that some categories of controlling shareholders, like institutional investors, banking institutions and industrial companies could be a source of advanced techniques, expertise and knowledge allowing banks to manage diverse activities where they potentially lack experience. Hence, banks with a significant presence of these

\footnotetext{
${ }^{1}$ For more details on the prevalence of multilayer ownership structures in the world, see, e.g., La Porta et al., 1999; Claessens et al., 2000; and Faccio and Lang, 2002.
} 
shareholder categories could diversify more promptly than widely-held banks (i.e., banks with no controlling shareholder) and enjoy economies of activity diversification.

To investigate the role of certain shareholder categories in mitigating diseconomies of diversification, we use a hand-collected data on multilayer ownership structures (i.e., control chains) of 710 commercial banks based in 17 Western European countries where the presence of multilayer ownership structures is more important than in other Western countries. We identify all shareholders involved in the bank's control chain and classify them into five categories: banking institutions, institutional investors, industrial companies, families and states. We then test whether the presence of some of these controlling shareholders could shape diversification performance by potentially affecting banks' expertise in managing their activities over the 2002-2010 period. Banks can diversify into new non-interest or interest income products or to services that are directly linked to an existing activity. Banks can also diversify within either non-interest income or interest income generating activities. We hence consider banks' activity diversification that occur either through shifts between non-interest income and interest income generating activities or through diversification within non-interest income generating activities. We capture banks' performance using profitability, earnings volatility and insolvency measures based on accounting data but also on market data.

We find that diversification performance differs according to the categories of shareholders involved in the bank's control chain. More precisely, the results show that activity diversification is associated with higher earnings volatility and higher default risk when banks are widely-held or have only families and states as controlling shareholders. This is possibly because families and states lack experience to manage diverse activities and, as a consequence, they are unable to deliver skills to their banks to allow for a successful activity diversification. However, banks involving as controlling shareholders other banking institutions, institutional investors and industrial companies benefit from diversification economies, meaning that they enjoy higher profitability and exhibit lower earnings volatility and insolvency. Consistent with our conjecture, these results suggest that, unlike family and state owners, the presence of institutional investors, banking institutions as well as industrial companies in banks' control chains is a source of additional skills and expertise allowing banks to reap the benefits from more diverse activities.

We also take our investigation further and examine whether the effectiveness of these controlling shareholders in mitigating diseconomies of diversification is more or less pronounced under particular conditions. Consistent with the home field advantage view (e.g., 
Lensink and Naaborg, 2007), we find that the observed mitigating roles are greater for domestic owners than for foreign ones. The results also show that, as long as the bank is controlled by a single ultimate owner, intermediate controlling shareholders are effective in mitigating diseconomies of diversification regardless of the extent of their financial interests held in the bank. This is consistent with our conjecture that an ultimate owner, when she/he is the only one who lastly benefit from a successful diversification, should have greater incentives to encourage intermediate shareholders to cooperate and transmit their skills to banks. Moreover, the results show that diversified owners are more efficient in mitigating diseconomies of diversification. Finally, we find that, although both large and small banks benefit from the presence of those shareholders, diversification benefits are greater for small banks. This is consistent with the view that small banks may suffer more from the lack of expertise to manage diverse activities (e.g., Mercieca et al., 2007) and, as a consequence, they should benefit more from the technology transmitted by controlling shareholders.

This study contributes to the literature in three directions. Firstly, our paper builds a bridge between the bank's organizational aspect and diversification performance within complex shareholding relationships by analyzing whether banks controlled by certain categories of shareholders are better able to benefit from their diversification strategy. Secondly, our study uses a broader dataset on multilayer ownership structures and adds to the literature by constructing several ownership indicators. Thirdly, our paper focuses on why banks suffer or benefit from their diversification strategy and sheds light on the fact that diseconomies of diversification in European banks come, at least partially, from the lack of expertise in managing diverse activities. From a policy perspective, this finding may be of help in the discussion of policy recommendations with regards to more stringent activity restrictions in European countries (IMF, 2011; ICB, 2011; Liikanen, 2012).

The remainder of the paper is organized as follows. Section 2 discusses the relevant literature and Section 3 presents the data and the model. In Section 4, we present the sample characteristics and some univariate analyses. Section 5 discusses the regression results and Section 6 concludes the paper.

\section{Related literature and hypotheses development}

Over the last three decades, banks have expanded their income sources by undertaking non-interest income generating activities such as securities and insurance underwriting, brokerage and mutual fund services, venture capital and asset securitization. The existing 
literature testing the implications of activity diversification on banks' profitability and risk provides inconclusive findings.

Most studies dedicated to the U.S. banking industry find that greater involvement in noninterest activities leads to higher profitability but also to higher risk because of the increased volatility of these activities. For instance, DeYoung and Roland (2001), Stiroh (2004), and Stiroh and Rumble (2006) find that a shift towards non-interest activities worsens the riskreturn trade-off. In a recent study, DeYoung and Torna (2013) find that expansion to nontraditional activities affected the probability of U.S. banks failure during the financial crisis and that this effect depends on banks' financial conditions. Specifically, they show that higher involvement in nontraditional activities is associated with higher probability of failure for financially distressed banks and the opposite is the case for healthy banks. Conversely, some U.S. based studies show that banks have potential benefits to expand the scope of their activities. For instance, Gallo et al. (1996) find that at some extent combining bank and mutual fund activities improves profitability and reduces risk of U.S. bank holdings companies over the 1987-1994 period.

Similarly, studies based on European banks provide conflicting results regarding the effect of diversification on bank performance. Mercieca et al. (2007) find that small European banks do not gain from their diversification strategy; the share of non-interest income is inversely related to profitability and positively to risk implying lower risk-adjusted returns. The authors explain such a finding by a lack of expertise of small banks in managing new lines of business and diverse activities. Lepetit et al. (2008) find that European banks expanding into noninterest income generating activities display higher risk and higher insolvency. This finding is mainly attributed to small banks and is essentially driven by commission and fee-based activities. Analyzing the effect of diversification on systemic risk of European banks, De Jonghe (2010) finds that non-interest generating activities increase banks' tail beta, reducing banking system stability.

Conversely, Vennet (2002) investigates the cost and profit efficiency of European banks and finds that financial conglomerates display better cost and profit efficiencies than focused banks. Similarly, Baele et al. (2007) find that activity diversification is associated with higher franchise values and lower idiosyncratic risk for a sample of banks established in 17 Western European countries over the period 1989-2004. Analyzing Italian banks, Chiorazzo et al. (2008) show that greater activity diversification improves the risk-return trade-off and that such diversification gains are stronger for large banks. 
Besides, some recent studies on emerging markets show that diversification effects on the risk-return trade-off are mainly driven by differences in ownership structures, with still contrasting results. Berger et al. (2010) find evidence of a diversification discount for a sample of Chinese banks over the 1996-2006 period and show that this discount is stronger for domestic banks than for foreign ones. The authors explain this diversification discount by the shortage of managerial expertise of the management teams. Similarly, Pennathur et al. (2012) examine the impact of ownership structure on income diversification and risk for Indian banks over the 2001-2009 period. They find that public sector banks are significantly less involved in non-interest activities. They also document that a shift to fee-based activities benefits public sector banks by reducing risk and default risk but the opposite is the case for both private domestic and foreign banks. In the case of Philippine banks, Meslier et al. (2014) find that income diversification improves profitability and risk-adjusted profitability. Such diversification economies are significantly stronger for foreign banks than domestic ones.

In this paper, we aim to test whether banks controlled by certain categories of shareholders are better able to reap benefits of activity diversification than banks with dispersed ownership (i.e., widely-held banks).

Some categories of shareholders have expertise in managing various activities and could bring additional experience, allowing the bank to easily diversify. For instance, institutional investors are generally larger, hold sufficiently diversified portfolios and have expertise in processing information at a lower cost (Pound, 1988). Institutional investors are also generally involved in term and riskier syndicated loans (Lim et al., 2014) and therefore have a habit to manage riskier activities. Moreover, as suggested by some earlier works (e.g., Diamond, 1991; Rajan, 1992), banking institutions acquire valuable information about clients during the process of making loans that facilitates the efficient provision of other financial services such as the underwriting of securities, and vice versa. Similarly, industrial companies might hold sufficiently diversified asset portfolios (Barry et al., 2011). As major shareholders in some countries (like in Europe), industrial companies could also play an important role in governing banks and acquiring valuable information. Taken together, these arguments suggest that, as controlling shareholders, banking institutions, institutional investors and industrial companies can transmit the acquired information to their banks to manage diverse activities where the latter potentially lack experience. We hence test the following hypothesis: 
Hypothesis 1. A shift from dispersed ownership to these categories of shareholders (i.e., banks, institutional investors and industrial companies) or any combination of these should improve the diversification performance.

In contrast, other shareholders (like families) limit executive management positions to family members which might restrict labor pool to obtain qualified talent. Families and states could also see innovation and openness as potential threats to their control and might be reluctant to finance innovations (Morck et al., 2000). This suggests that compared to the remaining categories of shareholders, family and state shareholders might be less effective in delivering managerial expertise beyond the existing one. Hence, we also test the following hypothesis:

Hypothesis 2. A shift from dispersed ownership to family or state ownership may not result in a more successful diversification strategy.

\section{Data and model}

Before presenting the empirical model and the set of variables, we describe the sample.

\subsection{Sample}

Our sample contains commercial banks established in 17 Western European countries: Austria, Belgium, Denmark, Finland, France, Germany, Greece, Ireland, Italy, Luxembourg, the Netherlands, Norway, Portugal, Spain, Sweden, Switzerland, and the United Kingdom. The sample period is from 2002 to 2010. We obtain bank accounting data from Bankscope. We mostly use unconsolidated data if available, otherwise we employ consolidated data. We check the robustness of the results using only unconsolidated data. To retrieve ownership data, we use both Bankscope and Amadeus databases as key sources, but also the annual reports disclosed in the websites. We collect macroeconomic data from the Bloomberg database. To be able to correctly calculate rolling-window standard deviations of our risk indicators, we restrict the initial sample to banks for which we have detailed information on the main financial variables for at least three years of time series observations. We mitigate the impact of outliers by winsorizing the main financial variables at the $1 \%$ and $99 \%$ levels. This gives rise to a final sample of 4,615 annual observations corresponding to 710 commercial banks, 105 of which are listed banks (see Table 1 for a classification of these banks by country). To assess the representativeness of the final sample, we compare the aggregate total assets of the sample banks in a given country with the aggregate assets of all the banks covered by Bankscope in the same country over the 2002-2010 period. The mean data coverage of the final sample lies at almost $80 \%$. 
[Insert Table 1 about here]

\subsection{Model specification and variables}

To test Hypotheses 1 and 2, we estimate the following dynamic model (e.g., Sanya and Wolfe, 2011; Wintoki et al., 2012) including a set of control variables (X) as well as vectors of country (Country) and year (Year) dummies:

$$
\begin{aligned}
y_{i t} & =\left[\alpha_{0}+\sum_{j=1}^{5} \alpha_{j} d\left(\text { Category }_{j i t}\right)\right] \times \text { Diversity }_{i t}+\sum_{j=1}^{5} \gamma_{j} d\left(\text { Category }_{j i t}\right)+\lambda y_{i t-1}+\beta^{\prime} X \\
& +\varphi^{\prime} \text { Country }+\delta^{\prime} \text { Year }+\mu_{i}+\varepsilon_{i t}
\end{aligned}
$$

where, $y$ is a measure of bank performance (profitability and risk); Diversity is a measure of activity diversification; $d\left(\right.$ Category $\left._{j}\right)$ is a set of dummy variables which capture the presence of each of the five categories of shareholders we consider: banks, institutional investors, industries, families, or states; $\mu_{i}$ are bank fixed effects; and $\varepsilon$ is the error term.

The coefficient $\alpha_{0}$ measures the effect of greater activity diversification on the performance of widely-held banks. Widely-held banks are used as a benchmark against which we analyze whether a shift from dispersed ownership to a given category of shareholders (banks, institutional investors, industries, families, or states) or to any combination of these categories of shareholders results in an increase of economies of diversification or a decrease in diseconomies of diversification. Hence, the coefficients $\alpha_{j}$ measure the effect on diversification performance of a shift from banks with dispersed ownership to banks having as controlling shareholders other banking institutions, institutional investors, industrial companies, family investors, or states. More precisely, the test of Hypothesis 1 is provided by the coefficients $\alpha_{1}, \alpha_{2}$ and $\alpha_{3}$ as well as by their sum, while the test of Hypothesis 2 is provided by the coefficients $\alpha_{4}$ and $\alpha_{5}$ and their sum.

We now turn to the description of the main variables introduced in our regressions (see

Table 2 for summary statistics and more details on these variables).

\subsubsection{Measuring ownership structure}

To identify all shareholders involved in the bank's decision making, we first need to build indirect control chains of the sampled banks until we achieve their ultimate controlling owners. To identify each owner along the control chains, we fix a minimum percentage of shares above which the owner can exert effective control over the intermediate and the final 
corporations involved in the control chain. Following prior studies (e.g., Caprio et al., 2007; Laeven and Levine, 2008, 2009), we use a control threshold of 10\%. For robustness considerations, we increase the control threshold and recalculate ownership variables with a control level of $20 \%$ instead of $10 \%$. Based on this control threshold, we draw the control chain for each bank for three years of the sample period: 2004, 2006, and 2010. The first two years allow us to capture ownership structure before the financial crisis. The last year (2010) takes into account potential changes in ownership structure that may have come from government intervention during the financial crisis. We choose the year 2004 as our starting point for ownership data rather than 2002 because before 2004, Bankscope and Amadeus do not provide information on the categories of shareholders. Ownership structure is known to be relatively stable over a short time period (e.g., La Porta et al., 1999; Laeven and Levine, 2009) and, as a consequence, building control chains for only three years of the sample period is reasonably accurate to capture the ownership structure. We assume that ownership of 2004 is similar to ownership of 2002 and 2003, ownership of 2006 is identical to ownership of 2005 and that ownership of 2007,2008 and 2009 comes from $2010 .^{2}$

To build control chains, we first identify direct shareholders holding at least $10 \%$ of the shares of each bank by collecting data from Bankscope and annual reports disclosed in the banks' websites. We consider as controlled, banks having at least one shareholder with $10 \%$ or more of shares and as widely-held, banks with no controlling shareholder. We then examine the ownership structure of these identified controlling shareholders. If these shareholders are family investors or states, we stop tracing the control chain and consider these to be the ultimate controlling owners. If, however, some or all of the controlling shareholders identified at this direct tier of the control chain are themselves financial or nonfinancial institutions, we go further and analyze the ownership structure of each owner found at an intermediate tier until we reach the ultimate owners. We collect ownership data on non-banking firms found as controlling shareholders at the intermediate tiers from the Amadeus database and annual reports available on websites.

We use these control chains to identify all intermediate and ultimate shareholders involved in the bank's control chain. We classify these shareholders into five categories: banks (Bank); institutional investors including insurance companies, mutual and pension funds, and financial companies (Institutional); industrial companies (Industry); managers, individuals or family

\footnotetext{
${ }^{2}$ To ensure that our results are not driven by the use of only three years of ownership data, we run our regressions by only considering the three years for which ownership is available: 2004, 2006 and 2010. The estimation results, not reported here but available on request, remain unchanged.
} 
investors (Family); and states or public authorities (State). We then define a set of dummy variables $[d($ Category $)]$ to capture the presence of each category of shareholders in the bank's control chain: $d$ (Bank), d(Institutional), d(Industry), d(Family), and $d$ (State) which take a value of one if at least one shareholder of the corresponding category is present in the bank's control chain, and zero otherwise. In line with the aim of the paper, we do not look at the effect of ultimate owners solely (e.g., Lins, 2003; Lins et al., 2013; Amit et al., 2015) but we consider the effect of all intermediate and ultimate owners involved in the bank's control chain. By considering both intermediate and ultimate owners we get dummy variables that are not mutually exclusive, meaning that a given bank could have all categories of shareholders in the control chain and, as a consequence, the five dummy variables can simultaneously take a value of one. This approach allows us to assess the diversification performance for any combination of shareholder categories. The experience of a certain category of shareholders should depend only on the category itself and not on the number of shareholders of such a category that are present in the control chain. Therefore, the use of binary variables is reasonably accurate. ${ }^{3}$

We also use the control chains to assess control rights (i.e., the right to control) and cashflow rights (i.e., the right to receive dividends) of all intermediate and ultimate owners involved in the control chain which we use to compute some ownership indicators. The aggregate control rights $(C R)$ and the aggregate cash-flow rights $(C F R)$ of a shareholder are the sum of direct and indirect rights held in the bank. Direct rights (control or cash-flow rights) indicate the percentage of shares directly held in the bank. Following the last link method as initially proposed by La Porta et al. (1999), we compute indirect control rights as the percentage of shares held by the closest corporation to the bank. For robustness considerations, we also compute indirect control rights based on the weakest link method (e.g., Claessens et al., 2000; Faccio and Lang, 2002) under which indirect control rights are equal to the minimum percentage of shares held in the indirect control chain. Indirect cashflow rights are calculated as the product of the percentages of shares held by the shareholders along the indirect control chain linking the shareholder $s$ to the bank $i$. We set aggregate control rights and aggregate cash-flow rights equal to zero if the bank is widely-held.

The incentives of controlling shareholders to transmit their skills to the bank to easily diversify may increase with the extent of their financial interests in the bank. To capture such

\footnotetext{
${ }^{3}$ Besides the use of dummy variables, for robustness considerations we also define five variables that capture the proportion of each category of shareholders involved in the bank's control chain as the ratio of the number of shareholders of each category to the total number of shareholders in the control chain. Because the composition of the control chains is stable over time, our results are not affected by the use of dummy or continuous variables.
} 
incentives, we compute an ownership indicator CFRConcentration which takes into account the level and the dispersion of financial interests among all shareholders in the control chain:

$$
\text { CFRConcentration }_{\mathrm{i}}=\overline{\mathrm{CFR}}_{\mathrm{i}} \times\left(1-\mathrm{SDCFR}_{\mathrm{i}}\right) \text {, }
$$

where, $\overline{C F R}_{i}$ and $S D C F R_{i}$ are respectively the average and the standard deviation of cash-flow rights held by all the shareholders involved in the control chain of bank $i{ }^{4}$ More formally, $\overline{C F R}_{i}$ and $S D C F R_{i}$ are respectively computed as $\overline{\mathrm{CFR}}_{i}=\frac{1}{n} \sum_{s=1}^{n} \mathrm{CFR}_{\mathrm{s}, \mathrm{i}}$ and $\mathrm{SDCFR}_{\mathrm{i}}=$ $\sigma\left(\mathrm{CFR}_{\mathrm{s}, \mathrm{i}}\right)$, with $n$ refers to the number of shareholders in the control chain. If the bank is widely-held, we set $\overline{C F R}_{i}$ equal to zero and therefore the variable CFRConcentration is null too. Higher values of CFRConcentration indicate a higher likelihood that all shareholders cooperate to transmit their skills to the bank to allow for a successful diversification strategy.

Moreover, the ability of a shareholder to transmit skills and to influence the bank's decision making might also matter. We hence follow the same procedure and compute another indicator CRConcentration based on the control rights of all shareholders. ${ }^{5}$ Higher values of CRConcentration indicate higher ability of shareholders to transfer their skills, if any, to the bank and to influence its decision making.

Fig.1 reports an example of a control chain to clarify how we define our ownership measures. The control chain of the reported bank is composed of nine controlling shareholders: two banking institutions (S2 and S4), three institutional investors (S1, S7 and S8), one industrial company (S5), two family investors (S3 and S9), and one state (S6). Cashflow rights of each shareholder $\left(C F R_{S}\right)$ are computed as: $C F R_{1}(\mathrm{~S} 1)=20 \% ; C F R_{2}(\mathrm{~S} 2)=6 \%$; $C F R_{3}(\mathrm{~S} 3)=30.9 \% ; C F R_{4}(\mathrm{~S} 4)=20 \% ; C F R_{5}(\mathrm{~S} 5)=3 \% ; C F R_{6}(\mathrm{~S} 6)=0.6 \% ; C F R_{7}(\mathrm{~S} 7)=$ $15 \% ; C_{8}(\mathrm{~S} 8)=4.5 \% ; \operatorname{CFR}_{9}(\mathrm{~S} 9)=0.9 \% . \overline{C F R}$ is then computed as: $\overline{\mathrm{CFR}}=\frac{1}{9} \sum_{\mathrm{s}=1}^{9} \mathrm{CFR}_{\mathrm{s}}=11.21 \%$. SDCFR $=\sigma\left(\mathrm{CFR}_{\mathrm{s}}\right)=0.10$, with the values of $C F R_{s}$ used to compute SDCFR are not expressed in percentages. CFRConcentration is therefore computed as: $11.21 \% \times(1-0.10)=10.09 \%$. We follow the same procedure to compute

CRConcentration. Control rights of each shareholder are: $C R_{1}(\mathrm{~S} 1)=C R_{2}(\mathrm{~S} 2)=20 \% ; C R_{3}$ $(\mathrm{S} 3)=50 \% ; C R_{4}(\mathrm{~S} 4)=C R_{5}(\mathrm{~S} 5)=C R_{6}(\mathrm{~S} 6)=20 \% ; C R_{7}(\mathrm{~S} 7)=C R_{8}(\mathrm{~S} 8)=C R_{9}(\mathrm{~S} 9)=15 \%$.

\footnotetext{
${ }^{4}$ For robustness considerations, we also define CFRConcentration based only on shareholders that are expected to bring additional skills to the bank (i.e., banks, institutional investors and industrial companies). The estimation results, not reported here but available on request, remain unchanged.

${ }^{5}$ Unlike control rights, cash-flow rights are highly correlated with the layer to which each shareholder belongs: the higher the cash-flow rights the closer is the shareholder to the bank. Hence, unlike CRConcentration the variable CFRConcentration takes into account differences in the position of shareholders within the control chain.
} 
$\overline{\mathrm{CR}}=\frac{1}{9} \sum_{\mathrm{s}=1}^{9} \mathrm{CR}_{\mathrm{s}}=21.66 \% . \mathrm{SDCR}=\sigma\left(\mathrm{CR}_{\mathrm{s}}\right)=0.11$. CRConcentration is then computed as: $21.66 \% \times(1-0.11)=19.28 \%$.

[Insert Fig.1 about here]

\subsubsection{Performance, product diversification and control variables}

We use various accounting-based indicators to assess bank performance (profitability and risk). We measure profitability for each bank using the return on assets computed as the ratio of net income to total assets $(R O A)$. We use the return on assets rather than the return on equity $(R O E)$ in order not to have our main results contaminated by differences in the leverage ratio. As a measure of bank risk-taking, we use the standard deviation of the return on assets (SDROA) which we compute on a rolling-window of three years $([\mathrm{t}-2, \mathrm{t}])$, but also on a rolling-window of five years $([\mathrm{t}-4, \mathrm{t}])$ for robustness considerations. Higher values of $S D R O A$ indicate higher risk-taking. We also compute a risk-adjusted profitability measure $(R A R O A)$ which we define as the ratio of the return on assets to its three-year rolling-window standard deviation. Finally, we consider a measure of default risk for each bank by computing the Z-Score (ZScore) following Boyd and Graham (1986) as: ZScore $=(\mathrm{ROA}+$ Equity)/SDROA, where Equity is the ratio of total equity to total assets. Lower values of both RAROA and ZScore denote respectively a higher risk and a higher probability of failure. ${ }^{6}$

We capture the degree of product diversification using bank income structure. Ideally, we would like a detailed breakdown on bank income and data on the extent to which banks underwrite securities, operate mutual funds, securitize assets, provide brokerage services, and so on. These details allow us to accurately test the effect of the presence of some categories of shareholders in the control chain on diversification performance. Data availability, however, restricts our ability to measure the diversification of activities for both publicly-listed and privately-owned banks. Given this data constraint, we use two diversification measures. The first measure referred to as Income Diversity captures the degree of diversification between interest and non-interest generating activities:

\footnotetext{
${ }^{6}$ Besides the use of accounting performance measures, to check the robustness of the results we also compute several marketbased indicators for the subsample of 105 publicly-listed banks. We consider a profitability measure (Return) defined as the average of daily bank stock returns for a calendar year. Risk-taking is defined as the standard deviation of daily bank stock returns for a calendar year (SDReturn). We measure default risk using two indicators: (i) a market data based ZScore defined as: MZScore $=\frac{100+\text { Return }}{\text { SDReturn }}$, where Return and SDReturn are in percentages and (ii) the Merton's distance to default $(D D)$. We compute the Merton's distance to default using both accounting and market variables: (i) debt of one year maturity which we interpolate using the cubic spline method to get daily observations, (ii) daily market value of equity and (iii) the three-month interbank risk-free rate. The estimation results obtained using market-based measures, not reported here but available on request, lead to similar conclusions.
} 


$$
\text { Income Diversity }=1-\left[\left(\frac{\text { Net Interest Income }}{\text { Net Operating Income }}\right)^{2}+\left(\frac{\text { Net Noninterest Income }}{\text { Net Operating Income }}\right)^{2}\right]
$$

where, Net Operating Income is the sum of Net Interest Income and Net Noninterest Income. ${ }^{7}$ The second measure referred to as Noninterest Income Diversity captures the degree of diversification within non-interest activities by disaggregating non-interest income into two components as follows:

$$
\text { Noninterest Income Diversity }=1-\left[\left(\frac{\text { Fee Income }}{\text { Net Noninterest Income }}\right)^{2}+\left(\frac{\text { Trading Income }}{\text { Net Noninterest Income }}\right)^{2}\right] \text {, }
$$

where, Net Noninterest Income is the sum of Fee Income (fee and commission income) and Trading Income (trading income and other non-interest income). By construction, both measures range between zero and a half. Income Diversity (Noninterest Income Diversity) is equal to zero when diversification reaches its minimum, meaning that net operating income (net non-interest income) stem entirely either from interest based activities (fee/commission generating activities) or from non-interest based activities (trading activities). They are equal to a half when there is a complete diversification. ${ }^{8}$

We introduce in the regressions a set of control variables that are highlighted by the existing literature to affect bank performance: the divergence between control and cash-flow rights (ExcessControl) defined as the difference between aggregate control rights and cash-flow rights of the largest ultimate owner (i.e., the one with the highest aggregate control rights); the natural logarithm of bank total assets $[\log ($ Assets $)]$ to account for bank size; the ratio of equity to total assets (Equity) to control for bank capitalization; the ratio of deposits to total assets (Deposits) to account for the funding structure; the ratio of loans to total assets (Loans) to control for the bank business model; a dummy variable $d$ (Listed) to account for the public and private status of banks; and finally the growth rate of the real gross domestic product (GDPGrowth) to take into account differences in the macroeconomic environment.

[Insert Table 2 about here]

\footnotetext{
${ }^{7}$ Because loans can produce fee and commission income, the income-based diversification measure may overestimate the extent to which banks engage in nontraditional activities (e.g., Laeven and Levine, 2007). Hence, as a robustness check, we use an asset-based diversification measure which captures the degree of diversification among loans and other earning assets. The estimation results, not reported here but available on request, remain unchanged.

${ }^{8}$ Diversification effects (either positive or negative) on performance may have limits and become smaller when banks reach a higher level of diversification. Hence, for robustness considerations we account for such non-linearity by including in our regressions the quadratic term of the diversification measures like for instance in Stiroh (2004).
} 


\section{Sample characteristics and univariate analyses}

We first present the ownership characteristics of the sample banks. Then, we look into the diversification performance of banks classified according to the categories of shareholders they involve in their control chains. ${ }^{9}$

\subsection{Ownership characteristics of banks in Western Europe}

Our dataset indicates that around $13 \%$ of the observations relate to widely-held banks and $87 \%$ to banks that are controlled by at least one shareholder. The number of shareholders involved in the control chains of banks ranges from one to 64 . Among controlled banks, more than $90 \%$ of the observations relate to banks with at least two shareholders in their control chains. ${ }^{10}$ We report in Table 3 information on the distribution of the sample according to the composition of banks' control chains. The table shows that other banking institutions and institutional investors are strongly involved in our sample both as intermediate and ultimate controlling shareholders. Some of the banking shareholders coincide with publicly-listed banks that are present in our sample. For instance, the Deutsche Bank AG which is the largest bank in our sample appears also as an ultimate controlling owner of a number of other banks in the sample. Individuals/families (Family) and states (State) are evenly present as intermediate and ultimate owners of banks. In contrast, industrial companies (Industry) are frequent as intermediate shareholders but less present as ultimate controlling owners.

Banks' ownership structure might at some extent change over time. To be able to examine variations in ownership structure, we restrict the sample to 400 controlled banks for which we have information for at least two years for which ownership is available, i.e. 2004, 2006 and 2010. Overall, the data show that the ownership structure of European banks is stable over time: $85 \%$ of the observations relate to banks for which the composition of the control chain remains unchanged over the sample period. Among the 400 banks we identify, ownership structure changed over time for only 45 banks. Unlike other shareholder categories, family ownership is generally stable. While the average institutional ownership has increased mainly during the first half of the sample period (2004-2006), the presence of banking institutions and industrial companies has decreased during the same period. State ownership also experienced a significant increase especially during the 2006-2010 and 2004-2010 periods. A possible explanation is the fact that a large part of state ownership may have come from

\footnotetext{
${ }^{9}$ We perform similar analyses on the subsamples of publicly-listed and privately-owned banks. The results, not reported here but available on request, indicate that both subsamples of banks follow almost similar characteristics as the whole sample.

${ }^{10}$ For robustness considerations, we run regressions by excluding from the initial sample banks having only one shareholder (corresponding to 460 observations). The estimation results, available on request, remain the same.
} 
massive government intervention by capital injections or nationalizations during the 2008 financial crisis. This increase in state ownership explains partly why the proportion of state owners in our sample is quite higher (around 10\%) compared with previous studies (e.g., Faccio and Lang, 2002; Caprio et al., 2007).

\subsection{Ownership structure, product diversification and performance}

We first examine whether banks with different categories of shareholders exhibit differences in the extent to which they are diversified. The results (not tabulated) show that banks in the sample are relatively diversified among interest and non-interest activities but focused within the range of non-interest activities: most of non-interest income comes from commissions and fee-based activities rather than from trading activities. The data also show that the degree of bank diversification is not significantly different among all groups of banks classified according to the categories of shareholders. These sample characteristics allow us to correctly test our hypotheses.

We then analyze whether the diversification performance differs depending on the composition of the banks control chains. On the whole, considering the Income Diversity measure, the results in Table 4 show that unlike for other banks, activity diversification is associated with higher profitability and lower risk when banks involve institutional investors, banking institutions, and industrial companies as shareholders in their control chains. A possible explanation could be the involvement of those powerful shareholders with prior experience in managing a variety of activities and their strong association with better financial networks and partnerships. The results obtained using the Noninterest Income Diversity measure (not reported in Table 4) show almost similar characteristics.

\section{Econometric results}

In this section, we first examine whether banks benefit or suffer from their diversification strategy regardless of their ownership structure. We then analyze whether banks controlled by certain categories of shareholders are better able to reap the benefits of diversification than widely-held banks. We finally look more closely into the factors that might affect the effectiveness of such controlling shareholders in mitigating diseconomies of diversification.

We use the Blundell and Bond (1998) Generalized Method of Moments (GMM) to estimate the coefficients of the dynamic fixed effects model reported in Eq. (1). Banks' expansion into new activities is not exogenous because banks that perform better are able to choose specific diversification strategies meaning that causality may run from performance to 
diversification (e.g., Berger et al., 2010). Similarly, previous studies (e.g., Demsetz and Lehn, 1985; Almeida et al., 2011) indicate that ownership may be endogenous as it is affected by the firm's level of performance (profitability and risk). However, as explained before, in our case ownership is stable over the sample period and therefore causality should only run from ownership to bank performance (Chi, 2005). Furthermore, most of control variables are potentially endogenous. For instance, banks' size and capitalisation as well as their public/private status could depend on banks' performance. We hence apply GMM instruments (lagged values) to all independent variables except for time, country and ownership dummies as well as GDP growth that we consider as exogenous. We limit the number of instruments by restricting the lag range used to generate them to three. We check the validity of these instruments using the Hansen test (an over-identification test under the null that all instruments are valid) and the Arellano and Bond test for the absence of second order residual autocorrelation (AR2 test). We also ensure the absence of multicolinearity problems by computing the variance inflation factors (VIF), which have a mean value of 1.25 with a maximum of 1.92 and a minimum of 1.02 .

\subsection{Product diversification performance: baseline results}

As explained before, the literature highlights that activity diversification does not necessarily imply higher profitability and lower risk, but may on the contrary induce diseconomies. Therefore, as a first check we test the effect of activity diversification on banks' performance regardless of their ownership structure to shed light on whether European banks benefit or suffer from their diversification strategy. Table 5 reports the obtained results using income (Panel 1) and non-interest income (Panel 2) diversity measures. We find that both diversity measures are associated with higher profitability but also with higher risktaking and higher default risk, and this holds in almost all the regressions: the coefficient on the diversity measure is significant and positive for the profitability $(R O A)$ and the risk-taking (SDROA) proxies and negative for the default risk proxy (ZScore). Furthermore, the results indicate that the benefits accruing from activity diversification (i.e., the positive effect on profitability) do not outweigh the increase in earnings volatility (SDROA): the coefficient associated to the diversity measure is not significant in the regression where the dependent variable is risk-adjusted profitability $(R A R O A)$.

While these findings challenge the traditional intermediation theory (Diamond, 1984) which suggests that diversification reduces risk, they are aligned with the findings of some earlier works indicating that diversification gives rise to diseconomies. For instance, Laeven and 
Levine (2007) explain the diseconomies of diversification by agency problems between managers and shareholders. Other studies highlight that the diseconomies of diversification could be due to the fact that banks have less experience to manage diverse activities and this ultimately harms performance, reflected in more volatile earnings and higher insolvency risk (e.g., Mercieca et al., 2007). In any case, taken together, our results imply that banks in Europe suffer diversification diseconomies (i.e., higher risk).

Regarding control variables, some of them enter significant. Consistent with the expropriation effect (e.g., Azofra and Santamaria 2011, Saghi-Zedek and Tarazi, 2015) we find that the divergence between control and cash-flow rights (ExcessControl) is associated with lower profitability, higher risk-taking and higher default risk. However, the dummy variables included to account for the types of shareholders in the control chain are generally non-significant. The results also show that large banks are more profitable (higher ROA) than small banks but they also display a higher probability of failure (lower ZScore). In addition, better capitalized banks are more profitable (higher ROA) and less vulnerable (higher ZScore) but more risky (higher SDROA). Moreover, the results show that banks with larger deposit base are more profitable and exhibit a higher probability of failure. In contrast, banks more reliant on lending activities are less risky. Finally, the results show that the annual growth rate of the gross domestic product is positively related to profitability and negatively to risk.

[Insert Table 5 about here]

If the observed diseconomies of diversification (higher risk) are due, at least partially, to the lack of expertise of European banks to manage diverse activities, the presence of controlling shareholders with prior experience in managing some activities could help to mitigate such diseconomies. Our objective in the next subsection is therefore to test whether European banks controlled by certain categories of shareholders are better able to extract the benefits of activity diversification.

\subsection{Ownership structure and banks' diversification performance}

Table 6 reports the results of estimating the coefficients of Eq. (1) using income (Panel 1) and non-interest income (Panel 2) diversity measures for the sample banks over the 20022010 period. ${ }^{11}$ The results show that widely-held banks display higher profitability but also higher risk: the coefficient $\alpha_{0}$ is significant and positive for the profitability $(R O A)$ and the

\footnotetext{
${ }^{11}$ To check the robustness of the results, we rerun regressions separately on subsamples of crisis (2007-2010) and sound (2002-2006) years as well as on subsamples of publicly-listed and privately-owned banks. In both cases, the results, not reported here but available on request, remain unchanged.
} 
risk-taking (SDROA) proxies and negative for the default risk proxy (ZScore), and this holds in almost all the regressions irrespective of the diversity measure we consider. Consistent with Hypothesis 2, the results also show that neither family nor state controlling shareholders affect diversification performance: the coefficients $\alpha_{4}$ and $\alpha_{5}$ are not significant in all the regressions. This suggests that diversification performance is not different between widelyheld banks and banks for which the control chains include only family and/or state owners. However, consistent with Hypothesis 1, the results show that banking institutions, institutional investors and industrial companies, as shareholders involved in the control chains, help to mitigate diseconomies of diversification: the coefficients $\alpha_{1}, \alpha_{2}$ and $\alpha_{3}$ are significant in almost all the regressions and positive when the dependent variable is a profitability (ROA and RAROA) or a default risk proxy (ZScore), and negative when we consider a risk-taking proxy (SDROA). Coherently, the coefficient $\alpha_{3}$ associated to the variable $d$ (Industry) $\times$ Diversity is generally significant only at the $10 \%$ level and it is smaller in magnitude compared to the coefficients $\alpha_{1}$ and $\alpha_{2}$ associated respectively to $d$ (Bank) $\times$ Diversity and $d$ (Institutional) $\times$ Diversity. This means that industrial companies are less effective in mitigating diseconomies of diversification compared to banking institutions and institutional investors. Overall, the results show that when the control chain is composed of banking institutions, institutional owners, or industrial companies or any combination of these shareholder categories, activity diversification leads to higher profitability, less volatile earnings and lower default risk.

To examine the effect of the shareholder categories on banks' diversification performance, we compute the marginal effects from Eq. (1) as: $\frac{\partial y}{\partial \text { Diversity }}=\alpha_{0}+\sum_{j=1}^{5} \alpha_{j} d\left(\right.$ Category $\left._{j}\right)$. For instance, the parameters $\alpha_{0}+\alpha_{2}$ and $\alpha_{0}+\sum_{j=1}^{5} \alpha_{j}$ measure the effect of activity diversification on the performance of banks having only institutional investors and banks having all categories of shareholders in their control chains, respectively. To save space, we report in the table only the marginal effects on the main combinations of shareholder categories.

Our results are not only statistically significant but also economically meaningful. For instance (see Table 6), the regression where SDROA is the dependent variable suggests that risk will increase by almost $8 \%$ of its mean (from $0.47 \%$ to $0.50 \%$ ) if there is a one standard deviation increase in Income Diversity (12.41\%) when the bank is widely-held [i.e., when the five dummy variables $d$ (Category) are simultaneously equal to zero]. For the same increase in Income Diversity, bank risk will increase by almost $11 \%$ (from $0.47 \%$ to around $0.52 \%$ ) of its 
mean if the control chain includes family and/or state owners solely. But for such an increase in Income Diversity, risk falls by almost $11 \%$ of its mean (from $0.47 \%$ to $0.42 \%$ ) when the bank belongs to a control chain which is fully composed of institutional investors and by almost $8 \%$ of its mean (from $0.47 \%$ to $0.43 \%$ ) when the control chain has entirely banking institutions. ${ }^{12}$ For control chains composed of industrial companies solely, the effect of diversification on risk (SDROA) is not significant $\left(\alpha_{0}+\alpha_{3}\right.$ non-significant), confirming the intuition that industrial companies are effective in mitigating diseconomies of diversification but at a lesser extent compared to banking institutions and institutional investors. For such an increase in Income Diversity, bank risk decreases by almost $27 \%$ of its mean when the control chain includes the five categories of shareholders (from $0.47 \%$ to around $0.35 \%$ ).

[Insert Table 6 about here]

On the whole, our results suggest that the effect of activity diversification on performance depends on the presence and absence of some shareholder categories in the control chain to which the bank belongs. More precisely, banks suffer diseconomies of diversification (i.e., higher risk) when they are widely-held or when their control chains include family and/or state owners solely. However, when control chains involve banking institutions, institutional investors, industrial companies or any other combination of these categories of controlling shareholders, banks benefit from diversification economies (higher profitability, lower earnings volatility and lower default risk). These results are consistent with the expertise of institutional investors, banking institutions and industrial companies in managing some activities, which if, transferred to the bank can translate into better diversification performance.

\subsection{Ownership structure and banks' diversification performance: deeper investigations}

In this subsection, we go further by analyzing some factors that could reinforce or weaken the effectiveness of controlling owners in mitigating diseconomies of activity diversification. We consider bank level factors as well as shareholder level factors. For this purpose, we augment Eq. (1) by interacting each factor with the $d$ (Category) $\times$ Diversity variable. To save space, we only present the results obtained using the Income Diversity measure for the variables of interest. The results obtained using the Noninterest Income Diversity measure are qualitatively the same and they are available on request.

\footnotetext{
${ }^{12}$ For instance, for control chains composed only of institutional investors [i.e., $d$ (Institutional) $=1$ and $d($ Bank $)=d($ Industry) $=d($ Family $)=d($ State $)=0]$, the calculation is as follows: $\frac{\partial \text { SDROA }}{\partial \text { Asset Diversity }}=0.003-0.007=-0.004$. Hence, for a one standard deviation increase in Income Diversity (12.41\%), SDROA will decrease by $0.004 \times 12.41 \%$ (from $0.47 \%$ to $0.42 \%$ ).
} 


\subsubsection{Bank level factors}

First, we test whether the incentives of controlling shareholders to transmit information and skills to the bank to easily diversify increase with the concentration of their financial interests held in that bank. Second, because the ultimate owner is the one who will lastly reap the benefits of a successful diversification -especially from profit diversion-, she/he may have greater incentives to encourage intermediate shareholders to cooperate and transmit their skills to the bank. Hence, the mitigating roles played by controlling shareholders should be greater in the case of a single ultimate owner than in the presence of multiple ultimate owners. Third, small banks may suffer more from the lack of expertise to manage diverse activities (e.g., Mercieca et al., 2007) and, as a consequence, they should benefit more from the technology transmitted by controlling shareholders than large banks.

To capture such effects, we define three dummy variables. We differentiate banks with high and low ownership concentration and define a dummy variable d(CFRConcentration) which takes a value of one if the variable CFRConcentration is greater than the median value. To capture the effect of the multiplicity of ultimate owners and the effect of bank size, we define two dummy variables, $d$ (Single) and $d$ (Small), which, respectively, take a value of one if the bank is controlled by one ultimate owner and if the bank's total assets variable is below the median value. The results in Table 7 show that the presence of institutional investors, banking institutions and industrial companies is beneficial only when the bank is controlled by a single ultimate owner and that these benefits are present regardless of the degree of ownership concentration/dispersion within control chains. ${ }^{13}$ Coherently, the results also show that even though both large and small banks benefit from the presence of these controlling shareholders, the benefits are stronger for small banks.

[Insert Table 7 about here]

\subsubsection{Shareholder level factors}

First, we consider the effect of foreign ownership. Under the global advantage hypothesis, foreign owners are generally associated with better networks and partnerships, have superior skills and can bring substantial improvements in terms of technological advancement and risk management (Berger et al., 2001). However, under the home field advantage view (e.g., Lensink and Naaborg, 2007), domestic owners hold a home country advantage and should be more efficient in mitigating diseconomies of diversification than are foreign owners. To test

\footnotetext{
${ }^{13}$ The use of CRConcentration instead of CFRConcentration leads to similar conclusions. The results are available on request.
} 
these hypotheses, we distinguish between foreign and domestic owners and define a set of dummy variables $d\left(\right.$ Domestic $\left._{j}\right)$ which take a value of one if at least one shareholder of the category $j$ is domestic. Second, we test whether the effectiveness of a shareholder in mitigating diseconomies of diversification depends on the extent to which this shareholder is diversified. Publicly-listed controlling shareholders are expected to be more diversified and to have more skills and experience in different activities. We hence use the public nature of a controlling shareholder as a proxy for the degree of her/his diversification and define a set of dummy variables $d$ (ListedOwner $r_{j}$ ) which take a value of one if at least one shareholder of the category $j$ is publicly-listed. In some cases, Bankscope and Amadeus do not provide information on the owner's country especially when the owner is a family. Given the information we have, we only separate banking owners, institutional owners and industries (for which we have complete information) into foreign and domestic owners and into publicly-listed and privately-owned shareholders. This is not a serious shortcoming of this study because the remaining categories of owners (Family and State) are not found to affect the relationship between diversification and bank performance. Given this data constraint and for consistency, we exclude from the model the interactions between the diversity measure and the family and state dummies.

The results reported in Table 8 show that both domestic and foreign owners contribute to mitigate diseconomies of diversification but such mitigating roles are higher for domestic owners, consistent with the home field advantage view. ${ }^{14}$ Coherently, the results also show that publicly-listed owners are more efficient in mitigating diseconomies of diversification than privately-owned shareholders.

[Insert Table 8 about here]

\section{Conclusion}

The objective of this study is to empirically investigate whether banks controlled by certain categories of shareholders are better able to benefit from their diversification strategy. For this purpose, we build the control chains of 710 commercial banks established in 17 Western European countries during the 2002-2010 period and classify banks according to the composition of their control chains.

\footnotetext{
${ }^{14}$ Similarly, Claessens et al. (2001) investigate performance differences between domestic and foreign banks in developed and developing countries. They find that domestic banks have higher profits than foreign banks in developed countries and the opposite is the case in developing countries. This might explain why our results obtained on developed countries do not corroborate those obtained by prior studies which focus on emerging countries (e.g., Berger et al., 2010; Pennathur et al., 2012). As an additional analysis, we would like to differentiate European and Non-European foreign owners and test whether the former are more effective in mitigating diseconomies of diversification. However, a deeper look to the data shows that most of foreign owners come from European countries.
} 
On the whole, our results show that diversification performance depends on the categories of shareholders involved in the bank's control chain. More specifically, the results indicate that greater activity diversification is associated with higher risk and higher default risk when banks have no controlling shareholder or have only families and states as controlling shareholders. However, banks having as controlling shareholders other banking institutions, institutional investors and industrial companies enjoy economies of diversification: they display higher profitability, lower risk and lower default risk. This result is consistent with our prediction that unlike family and state shareholders, the presence of institutional investors, banking institutions as well as industrial companies in the bank's control chain is a source of additional skills and expertise which help the bank to reap the benefits accruing from activity diversification. A deeper analysis shows that such mitigating roles are greater for domestic and diversified owners and that small banks benefit more from the presence of such powerful shareholders than large banks. The results also show that as long as the bank is under the control of one ultimate owner, intermediate controlling shareholders are effective in constraining diseconomies of diversification regardless of the extent of their financial interests held in the bank.

From a policy perspective, our findings suggest that banks' supervisors and regulators should consider the effect of ownership structure when evaluating the impact of more stringent activity restrictions on bank performance. In countries where banks are likely to be widely-held or to be controlled by state or family owners, greater activity diversification is likely to yield diseconomies. But, in countries with concentrated ownership involving institutional investors, banking institutions and industrial companies, banks could enjoy economies of activity diversification thanks to the experience of their controlling shareholders in managing a wide range of activities. Furthermore, our study suggests that diseconomies of activity diversification in European banks arise, at least partially, from the shortage of experience in managing diverse activities. 


\section{References}

Almeida, H., Park, S.Y., Subrahmanyam, M.G., and Wolfenzon, D., 2011. The structure and formation of business groups: Evidence from Korean chaebols. Journal of Financial Economics 99, 447-475.

Amit, R., Ding, Y., Villalonga, B., and Zhang, H., 2015. The role of institutional development in the prevalence and performance of entrepreneur and family-controlled firms. Journal of Corporate Finance 31, 284-305.

Azofra, V., and Santamaría, M., 2011. Ownership, control, and pyramids in Spanish commercial banks. Journal of Banking and Finance 35, 1464-1476.

Baele, L., De Jonghe, O., and Vander Vennet, R. 2007. Does the stock market value bank diversification? Journal of Banking and Finance 31, 1999-2023.

Barry, T.A., Lepetit, L., and Tarazi, A., 2011. Ownership structure and risk in publicly held and privately owned banks. Journal of Banking and Finance 35, 1327-1340.

Berger, A.N., DeYoung, R., Genay, H., and Udell, G.F., 2001. Globalization of financial institutions: Evidence from cross-border banking performance. FRB Chicago Working Paper $\mathrm{N}^{\circ}$ 1999-25.

Berger, A.N., Hasan, I., and Zhou, M., 2010. The effects of focus versus diversification on bank performance: Evidence from Chinese banks. Journal of Banking and Finance 34, 1417-1435.

Blundell, R., and Bond, S., 1998. Initial conditions and moment restrictions in dynamic panel data models. Journal of Econometrics 87, 115-143.

Boyd, J. H., and Graham, S. L., 1986. Risk, regulation, and bank holding company expansion into non-banking. Quarterly Review 10(2), 2-17.

Caprio, G., Laeven, L., and Levine, R., 2007. Governance and bank valuation. Journal of Financial Intermediation 16, 584-617.

Chi, J., 2005. Understanding the endogeneity between firm value and shareholder rights. Financial Management 34, 65-76.

Chiorazzo, V., Milani, C., and Salvini, F., 2008. Income diversification and bank performance: Evidence from Italian banks. Journal of Financial Services Research 33, 181-203.

Claessens, S., Djankov, S., and Lang, H. P. L., 2000. The separation of ownership and control in East Asian corporations. Journal of Financial Economics 58(1-2), 81-112.

Claessens, S., Demirgüç-Kunt, A., and Huizinga, H., 2001. How does foreign entry affect domestic banking markets? Journal of Banking and Finance 25, 891-911.

De Jonghe, O., 2010. Back to the basics in banking? A micro-analysis of banking system stability. Journal of Financial Intermediation 19, 387-417. 
Demsetz, H., and Lehn, K., 1985. The structure of corporate ownership: Causes and consequences. Journal of Political Economy 93(6), 1155-1177.

DeYoung, R., and Roland, K.P., 2001. Product mix and earnings volatility at commercial banks: Evidence from a degree of total leverage model. Journal of Financial Intermediation 10, 54-84.

DeYoung, R., and Torna, G., 2013. Non-traditional banking activities and bank failures during the financial crisis. Journal of Financial Intermediation 22, 397-421.

Diamond, D.W., 1984. Financial intermediation and delegated monitoring. Review of Economic Studies 51, 393-414.

Diamond, D.W., 1991. Monitoring and reputation: the choice between bank loans and directly placed debt. Journal of Political Economy 99, 689-721.

Faccio, M., and Lang, H. P. L., 2002. The ultimate ownership of Western European corporations. Journal of Financial Economics 65(3), 365-395.

Gallo, J.G., Apilado, V.P., and Kolari, J.W., 1996. Commercial bank mutual fund activities: Implications for bank risk and profitability. Journal of Banking and Finance 20, 1775-1791.

International Monetary Fund, 2011. Making banks safer: Can Volcker and Vickers do it? IMF Working Paper $\mathrm{N}^{\circ} 11 / 236$.

Independent Commission on Banking, 2011. The final report recommendations. Vickers Report, London.

La Porta, R., Lopez-de-Silanes, F., and Shleifer, A., 1999. Corporate ownership around the World. Journal of Finance 54(2), 471-517.

Laeven, L., and Levine, R., 2007. Is there a diversification discount in financial conglomerates? Journal of Financial Economics 85, 331-367.

Laeven, L., and Levine, R., 2008. Complex ownership structures and corporate valuations. Review of Financial Studies 21(2), 579-604.

Laeven, L., and Levine, R., 2009. Bank governance, regulation and risk taking. Journal of Financial Economics 93, 259-275.

Lensink, R., and Naaborg, I., 2007. Does foreign ownership foster bank performance? Applied Financial Economics 17, 881-885.

Lepetit, L., Nys, E., Rous, P., and Tarazi, A., 2008. Bank income structure and risk: An empirical analysis of European banks. Journal of Banking and Finance 32, 1452-1467.

Liikanen, E., 2012. High-level Expert Group on reforming the structure of the EU banking sector. Brussels.

Lim, J., Minton, B.A., and Weisbach, M.S., 2014. Syndicated loan spreads and the composition of the syndicate. Journal of Financial Economics 111, 45-69. 
Lins, K.V., 2003. Equity ownership and firm value in emerging Markets. Journal of Financial and Quantitative Analysis 38, 159-184.

Lins, K.V., Volpin, P., and Wagner, H.F., 2013. Does family control matter? International evidence from the 2008-2009 financial crisis. Review of Financial Studies 26, 2583-2619.

Mercieca, S., Schaeck, K., and Wolfe, S., 2007. Small European banks: Benefits from diversification? Journal of Banking and Finance 31, 1975-1998.

Meslier, C., Tacneng, R., and Tarazi, A., 2014. Is bank income diversification beneficial? Evidence from an emerging economy. Journal of International Financial Markets, Institutions and Money 31, 97-126.

Morck, R.K., Stangeland, D.A., and Yeung, B., 2000. Inherited wealth, corporate control and economic growth: The Canadian disease. NBER Working Paper $\mathrm{N}^{\circ} 6814$.

Pennathur, A.K., Subrahmanyam, V., and Vishwasrao, S., 2012. Income diversification and risk: Does ownership matter? An empirical examination of Indian banks. Journal of Banking and Finance 36, 2203-2215.

Pound, J., 1988. Proxy contests and the efficiency of shareholder oversight. Journal of Financial Economics 20, 237-265.

Rajan, R.G., 1992. Insiders and outsiders: the choice between informed and arm's-length debt. Journal of Finance 47, 1367-1400.

Saghi-Zedek, N., and Tarazi, A., 2015. Excess control rights, financial crisis and bank profitability and risk. Journal of Banking and Finance 55, 361-379.

Sanya, S., and Wolfe, S., 2011. Can banks in Emerging Economies benefit from revenue diversification? Journal of Financial Services Research 40, 79-101.

Stiroh, K.J., 2004. Diversification in banking: Is non-interest income the answer? Journal of Money, Credit and Banking 36, 853-882.

Stiroh, K.J., and Rumble, A., 2006. The dark side of diversification: The case of US financial holding companies. Journal of Banking and Finance 30, 2131-2161.

Vennet, R.V., 2002. Cost and profit efficiency of financial conglomerates and universal banks in Europe. Journal of Money, Credit and Banking 34, 254-282.

Wintoki, M.B., Linck, J., and Netter, J., 2012. Endogeneity and the dynamics of internal corporate governance. Journal of Financial Economics 105, 581-606. 
Table 1

Distribution of European commercial banks and representativeness of the final sample

This table shows the breakdown of European commercial banks by country and the representativeness of the sample. To assess the sample's representativeness, we compute the ratio of aggregate total assets of the banks included in the final sample to aggregate total assets of all the banks provided in Bankscope from 2002 to 2010

\begin{tabular}{|c|c|c|c|}
\hline Country & Number of all banks & Number of listed banks & $\begin{array}{l}\text { Total assets of all sample banks divided by total } \\
\text { assets of all banks provided in Bankscope }(\%)\end{array}$ \\
\hline Austria & 30 & 4 & 68.412 \\
\hline Belgium & 22 & 1 & 91.176 \\
\hline Denmark & 45 & 29 & 95.566 \\
\hline Finland & 6 & 1 & 64.254 \\
\hline France & 89 & 9 & 79.322 \\
\hline Germany & 81 & 8 & 80.915 \\
\hline Greece & 16 & 9 & 97.336 \\
\hline Ireland & 13 & 3 & 58.771 \\
\hline Italy & 111 & 14 & 93.870 \\
\hline Luxembourg & 53 & 4 & 77.230 \\
\hline Netherlands & 22 & 3 & 30.459 \\
\hline Norway & 6 & 2 & 88.835 \\
\hline Portugal & 14 & 3 & 86.496 \\
\hline Spain & 37 & 8 & 98.069 \\
\hline Sweden & 15 & 2 & 93.189 \\
\hline Switzerland & 70 & 3 & 96.382 \\
\hline United Kingdom & 80 & 2 & 47.794 \\
\hline Total/Mean & 710 & 105 & 79.298 \\
\hline
\end{tabular}

Fig. 1

Example of a control chain

This figure provides an example of a control chain of a bank (BANK). S refers to each corporation presented in each box. Arrows represent equity stakes held by each corporation in the bank (BANK) or in other corporations in the control chain. The reported bank has nine controlling owners of which three are ultimate owners (S3, S6, and S9). Aggregate rights of each owner are the sum of direct and indirect rights. Direct rights (either control or cash-flow rights) refer to the percentage of shares directly held by the owner in the bank. Indirect control rights are computed on the basis of the last link method initially proposed by La Porta et al. (1999) as the percentage of shares held by the closest corporation to the bank. Indirect cash-flow rights are calculated as the product of the percentages of shares held by the shareholders along the indirect control chain. CR and CFR indicate aggregate control rights and aggregate cash-flow rights of each owner. Cash-flow rights of each shareholder are computed as: $\mathrm{CFR}_{1}(\mathrm{~S} 1)=20 \% ; \mathrm{CFR}_{2}(\mathrm{~S} 2)=20 \% \times 30 \%=6 \% ; \mathrm{CFR}_{3}(\mathrm{~S} 3)=20 \% \times 30 \% \times 15 \%+30 \%=30.9 \%$; $\mathrm{CFR}$ (S4) $=20 \% ; \mathrm{CFR}_{5}(\mathrm{~S} 5)=$ $20 \% \times 15 \%=3 \% ; \mathrm{CFR}_{6}(\mathrm{~S} 6)=20 \% \times 15 \% \times 20 \%=0.6 \% ; \mathrm{CFR}_{7}(\mathrm{~S} 7)=15 \% ; \mathrm{CFR}_{8}(\mathrm{~S} 8)=15 \% \times 30 \%=4.5 \% ; \mathrm{CFR}(\mathrm{S} 9)=15 \% \times 30 \% \times 20 \%=0.9 \%$. Ownership concentration of the bank (BANK) is defined as: CFRConcentration $_{\mathrm{i}}=\overline{\mathrm{CFR}}_{\mathrm{i}} \times\left(1-\mathrm{SDCFR}_{\mathrm{i}}\right)$, where

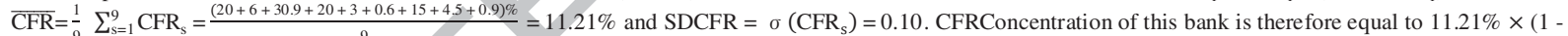
$0.10)=10.09 \%$. Control rights of each shareholder are: $\mathrm{CR}_{1}(\mathrm{~S} 1)=\mathrm{CR}_{2}(\mathrm{~S} 2)=20 \% ; \mathrm{CR}_{3}(\mathrm{~S} 3)=50 \% ; \mathrm{CR}_{4}(\mathrm{~S} 4)=\mathrm{CR}_{5}(\mathrm{~S} 5)=\mathrm{CR}_{6}(\mathrm{~S} 6)=20 \% ; \mathrm{CR}_{7}(\mathrm{~S} 7)=\mathrm{CR}_{8}(\mathrm{~S} 8)$ $=\mathrm{CR}_{9}(\mathrm{~S} 9)=15 \% \cdot \overline{\mathrm{CR}}=\frac{1}{9} \sum_{\mathrm{s}=1}^{9} \mathrm{CR}_{\mathrm{s}}=21.66 \% . \mathrm{SDCR}=\sigma\left(\mathrm{CR}_{\mathrm{s}}\right)=0.11$. CRConcentration is then: $21.66 \% \times(1-0.11)=19.28 \%$.

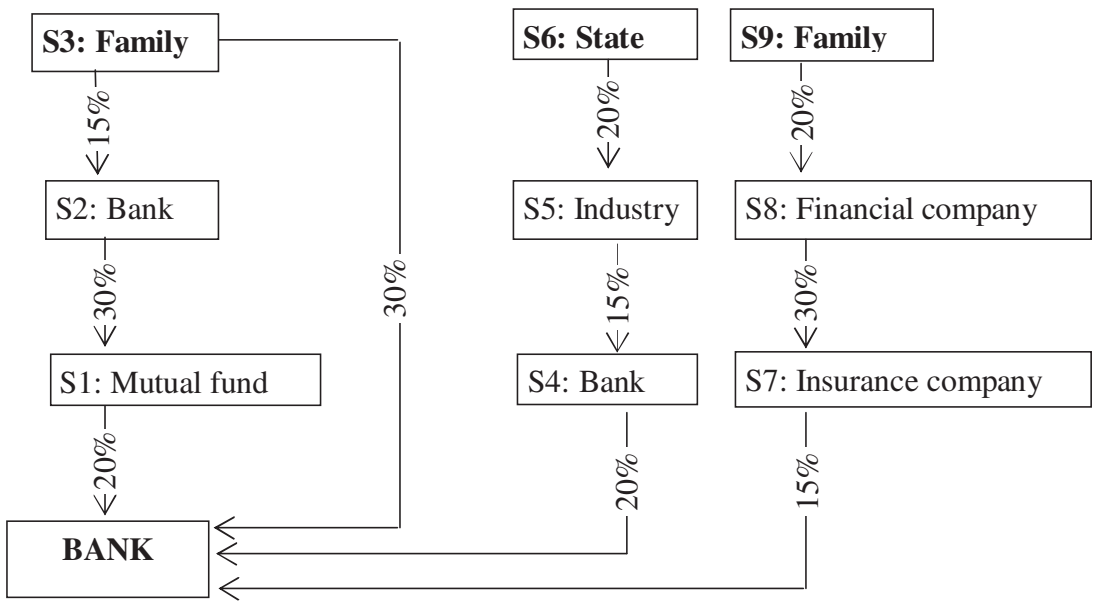




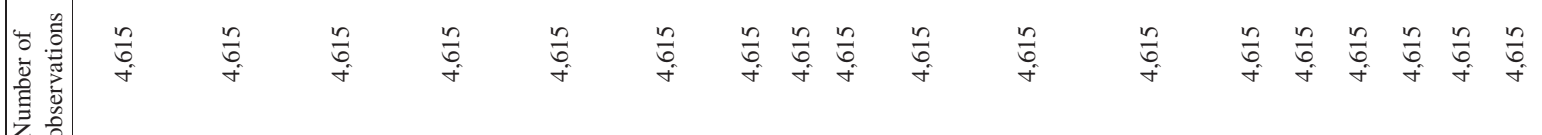

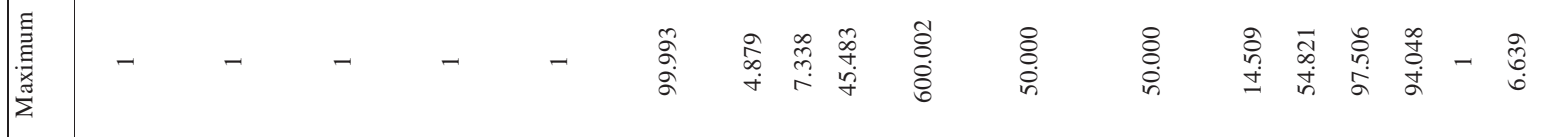

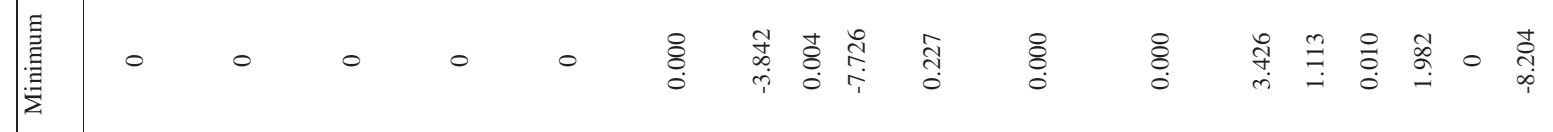

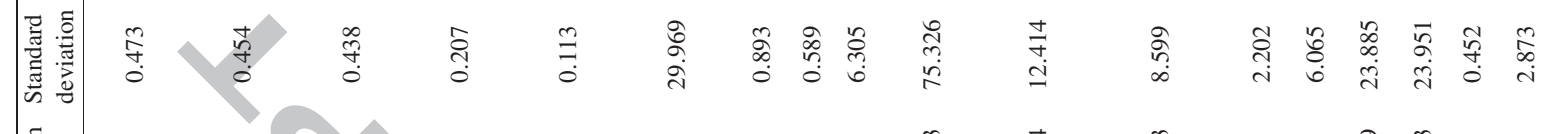

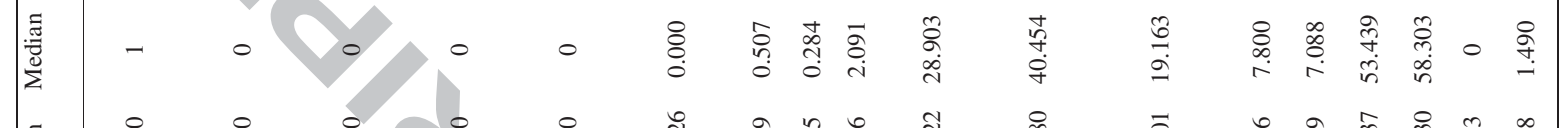

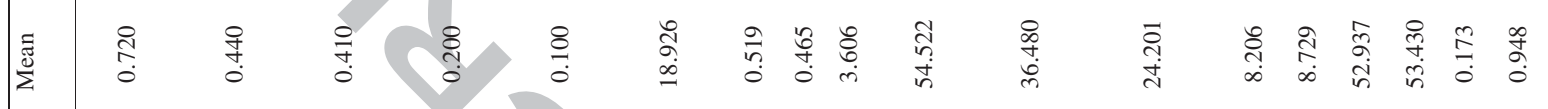

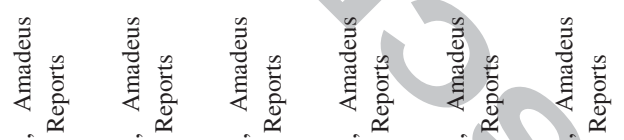

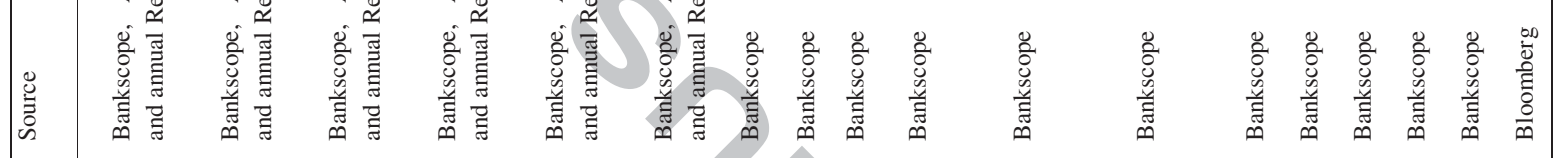

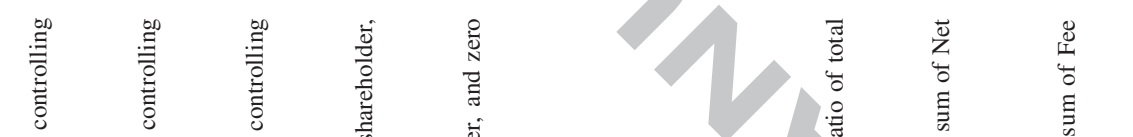

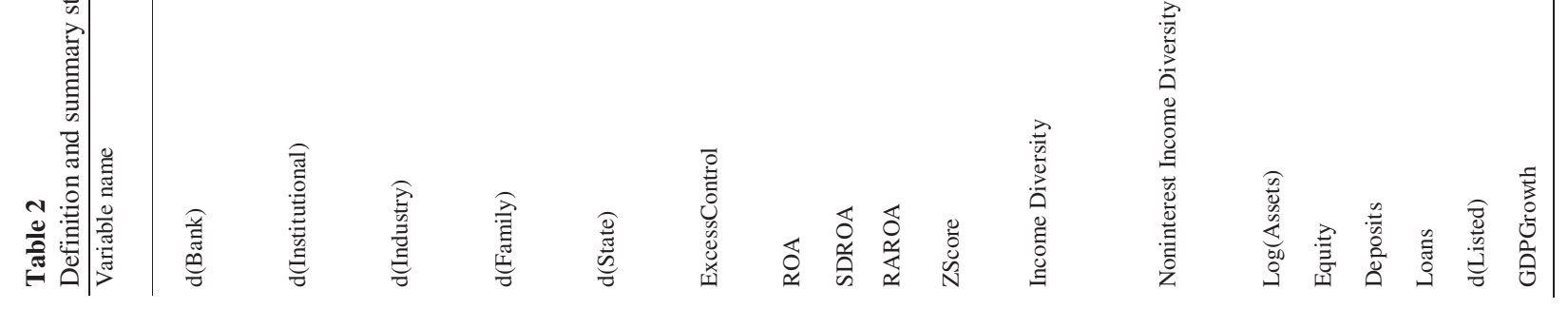


Table 3

Distribution of the sample by ownership type

This table reports information on the distribution of the sample banks according to the type of all shareholders in the control chains (Panel 1) and the type of ultimate owners (Panel 2), using a control threshold of $10 \%$. We classify the controlling shareholders involved in the control chains into five categories: a bank (Bank); a financial company, an insurance company, a mutual or a pension fund (Institutional); an industrial firm (Industry); an individual, a family or a manager (Family); a state or a public authority (State).

\begin{tabular}{lcc|c|c|c}
\hline & Bank & Institutional & Industry & Family & State \\
\hline \multicolumn{7}{l}{ Panel 1: classification of all shareholders in the control chains } \\
$\begin{array}{lccccc}\text { Number of observations } \\
\text { (percentage of observations) }\end{array}$ & 3,322 & 2,030 & 1,892 & 923 & 462 \\
Number of banks & $(71.983)$ & $(43.987)$ & $(40.997)$ & $(20.000)$ & $(10.011)$ \\
\hline Panel 2: classification of ultimate shareholders & 518 & 298 & 284 & 170 & 78 \\
\hline $\begin{array}{l}\text { Number of observations } \\
\text { (percentage of observations) }\end{array}$ & 1,530 & 898 & & 1,027 & 432 \\
Number of banks & $(37.217)$ & $(21.844)$ & $(5.449)$ & $(24.982)$ & $(10.508)$ \\
\hline
\end{tabular}

Table 4

Diversification performance by ownership type: univariate analyses

This table reports the performance (profitability and risk) of the sample banks according to the composition of their control chains and their degree of diversification over the 2002-2010 period. Using a control threshold of $10 \%$, we differentiate widely-held banks and controlled banks. d(Widely) is a dummy equal to one if the bank is widely-held (with no controlling shareholder), and zero otherwise. We classify the controlling shareholders involved in control chains into five categories: a bank (Bank); a financial company, an insurance company, a mutual or a pension fund (Institutional); an industrial firm (Industry); an individual, a family or a manager (Family); a state or a public authority (State). d(Bank), d(Institutional), d(Industry), d(Family), and d(State) are dummies equal to one if at least one shareholder of the corresponding category is present in the bank's control chain, and zero otherwise. We divide each group of banks into diversified and nondiversified banks. We consider as diversified (Diversified), banks with an above-median value of the Income Diversity measure and as non-diversified (Nondiversified), banks with a below-median value of the Income Diversity measure. ROA is the return on assets defined as net income divided by total assets. SDROA is the three-year rolling-window standard deviation of the return on assets. RAROA is the return on assets divided by its three-year rolling-window standard deviation. ZScore is a measure of bank default risk. T-statistics test for the null: "profitability and risk are not different between non-diversified and diversified banks inside each group". *,**, and *** indicate significance at the $10 \%, 5 \%$ and $1 \%$ levels, respectively, for a bilateral test.

\begin{tabular}{|c|c|c|c|c|}
\hline & ROA & SDROA & RAROA & ZScore \\
\hline \multicolumn{5}{|l|}{$\mathrm{d}($ Widely $)=1$} \\
\hline Non-diversified & 0.682 & 0.443 & 5.643 & 60.913 \\
\hline Diversified & 0.735 & 0.498 & 3.826 & 48.150 \\
\hline T-statistics & $-1.903 *$ & $-1.789 *$ & $2.044^{* *}$ & $2.254^{* * *}$ \\
\hline \multicolumn{5}{|l|}{$\mathrm{d}($ Bank $)=1$} \\
\hline Non-diversified & 0.527 & 0.473 & 3.030 & 51.600 \\
\hline Diversified & 0.626 & 0.415 & 3.865 & 55.596 \\
\hline T-statistics & $-2.930^{* * * *}$ & $1.715^{*}$ & $-2.172^{* *}$ & -0.875 \\
\hline \multicolumn{5}{|c|}{$\mathrm{d}($ Institutional $)=\mathbf{1}$} \\
\hline Non-diversified & 0.526 & 0.568 & 2.850 & 42.513 \\
\hline Diversified & 0.653 & 0.459 & 3.208 & 53.597 \\
\hline T-statistics & $-3.050^{* * *}$ & $1.759^{*}$ & $-1.649 *$ & $-1.667^{*}$ \\
\hline \multicolumn{5}{|l|}{$\mathrm{d}($ Industry $)=1$} \\
\hline Non-diversified & 0.562 & 0.598 & 2.267 & 49.781 \\
\hline Diversified & 0.670 & 0.445 & 4.287 & 59.427 \\
\hline T-statistics & $-2.175 * *$ & $2.121^{* *}$ & $-3.463^{* * *}$ & $-1.654^{*}$ \\
\hline \multicolumn{5}{|l|}{$d($ Family $)=1$} \\
\hline Non-diversified & 0.456 & 0.530 & 5.574 & 58.896 \\
\hline Diversified & 0.464 & 0.626 & 3.577 & 40.007 \\
\hline T-statistics & -0.552 & $-2.269^{* *}$ & 1.274 & $2.376^{* *}$ \\
\hline \multicolumn{5}{|l|}{$\mathrm{d}($ State $)=1$} \\
\hline Non-diversified & 0.387 & 0.239 & 4.551 & 57.995 \\
\hline Diversified & 0.490 & 0.291 & 3.991 & 47.733 \\
\hline T-statistics & -0.349 & -0.427 & 0.236 & $1.645^{*}$ \\
\hline
\end{tabular}




\section{Table 5}

Product diversification performance

This table shows the Blundell and Bond (1998) estimation results of the effect of product diversification on performance (profitability and risk) for a sample of European commercial banks over the 2002-2010 period. We here estimate this baseline equation: $\mathrm{y}_{\mathrm{it}}=\alpha_{0} \times$ Diversity $_{\mathrm{it}}+\sum_{\mathrm{j}=1}^{5} \gamma_{\mathrm{j}} \mathrm{d}\left(\right.$ Category $\left._{\mathrm{jit}}\right)+\lambda \mathrm{y}_{\mathrm{it}-1}+\beta^{\prime} \mathrm{X}+\varphi^{\prime}$ Country $+\delta^{\prime}$ Year $+\mu_{\mathrm{i}}+\varepsilon_{\mathrm{it}}$. We measure product diversification using income (Panel 1) and non-interest income (Panel 2) diversity measures. ROA is the return on assets defined as net income divided by total assets. SDROA is the three-year rolling-window standard deviation of the return on assets. RAROA is the return on assets divided by its three-year rolling-window standard deviation. ZScore is

a measure of bank default risk. Income Diversity is 1- $\left[\left(\frac{\text { Net Interest Income }}{\text { NetOperating Income }}\right)^{2}+\left(\frac{\text { Net Noninterest Income }}{\text { NetOperating Income }}\right)^{2}\right]$, with Net Operating Income is defined as the sum of Net Interest Income and Net Noninterest Income. Noninterest Income Diversity is $1-\left[\left(\frac{\text { Fee Income }}{\text { Net Noninterest Income }}\right)^{2}+\left(\frac{\text { Trading Income }}{\text { Net Noninterest Income }}\right)^{2}\right]$, with Net Noninterest Income is the sum of Fee Income and Trading Income. d(Bank), d(Institutional), d(Industry), d(Family), and d(State) are dummies equal to one if at least one shareholder of the corresponding category (Bank, Institutional, Industry, Family, State) is present in the bank's control chain, and zero otherwise. The definition of all control variables is provided in Table 2. In all the regressions, Country and Year dummies are included but not reported. Hansen test is a test of the overidentifying restrictions under the null of the absence of correlation between the instruments and the error term. AR2 test is a test of the absence of second order residual autocorrelation. P-values based on robust standard errors are shown in parentheses. *, ** and *** indicate statistical significance at the $10 \%, 5 \%$ and $1 \%$ levels, respectively.

\begin{tabular}{|c|c|c|c|c|c|c|c|c|}
\hline \multirow{2}{*}{$\begin{array}{l}\text { Diversity measures } \\
\text { Dependent variable }\end{array}$} & \multicolumn{4}{|c|}{ Panel 1: Income Diversity } & \multicolumn{4}{|c|}{ Panel 2: Noninterest Income Diversity } \\
\hline & ROA & SDROA & RAROA & ZScore & ROA & SDROA & RAROA & ZScore \\
\hline \multirow[t]{2}{*}{ Diversity $\left(\alpha_{0}\right)$} & $0.005 * *$ & $0.003 * *$ & 0.046 & $-2.628 * *$ & $0.003 *$ & $0.003 * *$ & -0.025 & $-3.132 * *$ \\
\hline & $(0.035)$ & $(0.022)$ & $(0.170)$ & $(0.011)$ & $(0.081)$ & $(0.041)$ & $(0.583)$ & $(0.033)$ \\
\hline \multirow[t]{2}{*}{ d(Bank) } & 0.021 & -0.043 & -0.141 & -6.512 & 0.006 & -0.038 & -0.281 & -10.146 \\
\hline & $(0.653)$ & $(0.401)$ & $(0.672)$ & $(0.420)$ & $(0.970)$ & $(0.452)$ & $(0.624)$ & $(0.202)$ \\
\hline \multirow[t]{2}{*}{ d(Institutional) } & 0.046 & 0.059 & -0.108 & -3.758 & -0.045 & 0.045 & -0.042 & -4.563 \\
\hline & $(0.514)$ & $(0.171)$ & $(0.796)$ & $(0.501)$ & & $(0.291)$ & $(0.941)$ & $(0.423)$ \\
\hline \multirow[t]{2}{*}{ d(Industry) } & -0.003 & 0.043 & -0.519 & -3.717 & -0.002 & 0.062 & -0.502 & -4.330 \\
\hline & $(0.921)$ & $(0.334)$ & $(0.258)$ & $(0.455)$ & (0.996) & $(0.332)$ & $(0.410)$ & $(0.352)$ \\
\hline \multirow[t]{2}{*}{ d(Family) } & $-0.350 * * *$ & -0.071 & 0.552 & 2.130 & $-0.382 * * *$ & -0.055 & 0.826 & 4.622 \\
\hline & $(0.001)$ & $(0.342)$ & $(0.534)$ & $(0.901)$ & $(0.000)$ & $(0.434)$ & $(0.232)$ & $(0.710)$ \\
\hline \multirow[t]{2}{*}{ d(State) } & 0.055 & $-0.263 * * *$ & 2.002 & $29.241 * *$ & 0.034 & $-0.251 * * *$ & 2.004 & $30.652 * *$ \\
\hline & $(0.662)$ & $(0.001)$ & $(0.313)$ & $(0.026)$ & $(0.656)$ & $(0.001)$ & $(0.431)$ & $(0.025)$ \\
\hline \multirow[t]{2}{*}{ ExcessControl } & $-0.002 * *$ & $0.001 *$ & $-0.024 * *$ & $-0.611^{* *}$ & $-0.002 * *$ & $0.001^{*}$ & $-0.023 *$ & $0.659 * *$ \\
\hline & $(0.015)$ & $(0.072)$ & $(0.032)$ & $(0.022)$ & $(0.041)$ & $(0.075)$ & $(0.066)$ & $(0.025)$ \\
\hline \multirow[t]{2}{*}{ Lagged dependent variable } & $0.163 * * *$ & & $0.459 * *$ & $0.521 * *$ & $0.159 * *$ & 0.030 & $0.385 * *$ & $0.473 * *$ \\
\hline & $(0.006)$ & $(0.125)$ & $(0.021)$ & $(0.025)$ & $(0.021)$ & $(0.310)$ & $(0.022)$ & $(0.032)$ \\
\hline \multirow[t]{2}{*}{ Log(Assets) } & $0.062 * *$ & -0.020 & -0.020 & $-4.625 * *$ & $0.067 * * *$ & $-0.021 *$ & -0.032 & $-3.612 * *$ \\
\hline & & $(0.110)$ & $(0.732)$ & $(0.015)$ & $(0.003)$ & $(0.081)$ & $(0.561)$ & $(0.011)$ \\
\hline \multirow[t]{4}{*}{ Equity } & $0.051 * *$ & $0.022 * * *$ & 0.010 & $4.121 *$ & $0.055 * * *$ & $0.019 * *$ & 0.006 & $4.215^{*}$ \\
\hline & $(0.012)$ & $(0.004)$ & $(0.510)$ & $(0.013)$ & $(0.004)$ & $(0.020)$ & $(0.891)$ & $(0.054)$ \\
\hline & $0.006 * *$ & 0.001 & 0.004 & $-0.210^{* *}$ & $0.006 * *$ & 0.000 & 0.009 & $-0.236 * *$ \\
\hline & $(0.020)$ & $(0.614)$ & $(0.512)$ & $(0.012)$ & $(0.031)$ & $(0.810)$ & $(0.315)$ & $(0.014)$ \\
\hline \multirow[t]{4}{*}{ Loans } & 0.003 & $-0.003^{* *}$ & $0.030 * *$ & $0.501 * *$ & 0.002 & $-0.003^{* * *}$ & $0.032 * * *$ & $0.510 * * *$ \\
\hline & $(0.311)$ & $(0.015)$ & $(0.010)$ & $(0.021)$ & $(0.321)$ & $(0.005)$ & $(0.008)$ & $(0.009)$ \\
\hline & 0.062 & -0.022 & 0.412 & -1.009 & 0.071 & -0.029 & 0.492 & -1.201 \\
\hline & $(0.512)$ & $(0.231)$ & $(0.613)$ & $(0.641)$ & $(0.415)$ & $(0.541)$ & $(0.513)$ & $(0.710)$ \\
\hline \multirow{2}{*}{ GDPGrowth } & $0.012 * *$ & $-0.011 * * *$ & $0.230 * *$ & 0.531 & $0.012 * *$ & $-0.012 * * *$ & $0.224 * *$ & 0.421 \\
\hline & $(0.031)$ & $(0.009)$ & $(0.022)$ & $(0.210)$ & $(0.027)$ & $(0.001)$ & $(0.021)$ & $(0.402)$ \\
\hline \multirow[t]{2}{*}{ Constant } & $-0.852 * * *$ & $0.526 * *$ & 0.505 & $60.914 * *$ & $-0.652 *$ & $0.495^{*}$ & 1.015 & $73.160 * *$ \\
\hline & (0.009) & $(0.010)$ & $(0.821)$ & $(0.015)$ & $(0.081)$ & $(0.089)$ & $(0.551)$ & $(0.011)$ \\
\hline Number of observations & 4,615 & 4,615 & 4,615 & 4,615 & 4,615 & 4,615 & 4,615 & 4,615 \\
\hline Number of banks & 710 & 710 & 710 & 710 & 710 & 710 & 710 & 710 \\
\hline Hansen test (p-value) & 0.201 & 0.610 & 0.212 & 0.432 & 0.231 & 0.711 & 0.193 & 0.440 \\
\hline AR2 test (p-value) & 0.181 & 0.112 & 0.172 & 0.191 & 0.169 & 0.112 & 0.156 & 0.181 \\
\hline
\end{tabular}




\section{Table 6}

Ownership structure and diversification performance

This table shows the Blundell and Bond (1998) estimation results of the effect of ownership type on diversification performance [Eq. (1)] for a sample of European commercial banks over the 2002-2010 period. We measure product diversification using income (Panel 1) and non-interest income (Panel 2) diversity measures. ROA is the return on assets defined as net income divided by total assets. SDROA is the three-year rolling-window standard deviation of the return on assets. RAROA is the return on assets divided by its three-year rolling-window standard deviation. ZScore is a measure of bank default risk. Income Diversity is 1- $\left[\left(\frac{\text { Net Interest Income }}{\text { Net Operating Income }}\right)^{2}+\left(\frac{\text { Net Noninterest Income }}{\text { Net Operating Income }}\right)^{2}\right]$, with Net Operating Income is defined as the sum of Net Interest Income and Net Noninterest Income. Noninterest Income Diversity is $1-\left[\left(\frac{\text { Fee Income }}{\text { Net Noninterest Income }}\right)^{2}+\left(\frac{\text { Trading Income }}{\text { Net Noninterest Income }}\right)^{2}\right]$, with Net Noninterest Income is the sum of Fee Income and Trading Income. $\mathrm{d}$ (Bank), d(Institutional), d(Industry), d(Family), and d(State) are dummies equal to one if at least one shareholder of the corresponding category (Bank, Institutional, Industry, Family, State) is present in the bank's control chain, and zero otherwise. The definition of all control variables is provided in Table 2. In all the regressions, Country and Year dummies are included but not reported. Hansen test is a test of the over-identifying restrictions under the null of the absence of correlation between the instruments and the error term. AR2 test is a test of the absence of second order residual autocorrelation. P-values based on robust standard errors are shown in parentheses. *,** and *** indicate statistical significance at the $10 \%, 5 \%$ and $1 \%$ levels, respectively.

\begin{tabular}{|c|c|c|c|c|c|c|c|c|}
\hline \multirow{2}{*}{$\begin{array}{l}\text { Diversity measure } \\
\text { Dependent variable }\end{array}$} & \multicolumn{4}{|c|}{ Panel 1: Income Diversity } & \multicolumn{4}{|c|}{ Panel 2: Noninterest Income Diversity } \\
\hline & ROA & SDROA & RAROA & ZScore & ROA & SDROA & RAROA & ZScore \\
\hline \multirow[t]{2}{*}{ Diversity $\left(\alpha_{0}\right)$} & $0.003 * *$ & $0.003 * * *$ & 0.047 & $-3.961 * *$ & 0.002 & $0.001 * *$ & -0.075 & $-3.679 * *$ \\
\hline & $(0.011)$ & $(0.002)$ & (0.513) & (0.013) & $(0.512)$ & $(0.014)$ & $(0.817)$ & $(0.012)$ \\
\hline \multirow[t]{2}{*}{$\mathrm{d}($ Bank $) \times$ Diversity $\left(\alpha_{1}\right)$} & $0.002 * *$ & $-0.006^{* *}$ & $2.010 * *$ & $9.802 * *$ & $0.002 * *$ & $-0.003 * *$ & $2.214 * *$ & $7.761 * *$ \\
\hline & $(0.023)$ & $(0.010)$ & $(0.031)$ & $(0.014)$ & $(0.013)$ & $(0.011)$ & $(0.031)$ & $(0.022)$ \\
\hline \multirow[t]{2}{*}{$\mathrm{d}($ Institutional $) \times$ Diversity $\left(\alpha_{2}\right)$} & $0.003 * * *$ & $-0.007 * * *$ & $2.951 * *$ & $10.120 * * *$ & $0.003 * *$ & $-0.004 * *$ & $2.772 * *$ & $9.021 * *$ \\
\hline & $(0.005)$ & $(0.003)$ & $(0.011)$ & $(0.003)$ & $(0.021)$ & $(0.022)$ & $(0.021)$ & $(0.031)$ \\
\hline \multirow[t]{2}{*}{$\mathrm{d}$ (Industry) $\times$ Diversity $\left(\alpha_{3}\right)$} & $0.001 *$ & $-0.002 *$ & $1.195 *$ & $8.041 *$ & $0.001 *$ & $-0.002 *$ & 0.361 & $6.701 *$ \\
\hline & $(0.065)$ & $(0.063)$ & $(0.073)$ & $(0.052)$ & $(0.082)$ & $(0.052)$ & $(0.211)$ & $(0.070)$ \\
\hline \multirow[t]{2}{*}{$\mathrm{d}\left(\right.$ Family) $\times$ Diversity $\left(\alpha_{4}\right)$} & 0.000 & 0.001 & -0.392 & -4.921 & -0.001 & -0.000 & 0.315 & -3.911 \\
\hline & $(0.901)$ & $(0.910)$ & $(0.345)$ & $(0.623)$ & $(0.662)$ & $(0.817)$ & $(0.523)$ & $(0.510)$ \\
\hline \multirow[t]{2}{*}{$\mathrm{d}($ State $) \times$ Diversity $\left(\alpha_{5}\right)$} & 0.000 & 0.001 & -0.401 & -5.011 & -0.000 & 0.001 & -0.021 & -3.412 \\
\hline & $(0.852)$ & $(0.521)$ & $(0.521)$ & $(0.525)$ & $(0.718)$ & $(0.428)$ & $(0.713)$ & $(0.612)$ \\
\hline Number of observations & & 4,615 & 4,615 & 4,615 & 4,615 & 4,615 & 4,615 & 4,615 \\
\hline Number of banks & 710 & 710 & 710 & 710 & 710 & 710 & 710 & 710 \\
\hline Control variables & Yes & Yes & Yes & Yes & Yes & Yes & Yes & Yes \\
\hline Hansen test (p-value) & 0.311 & 0.412 & 0.509 & 0.516 & 0.261 & 0.413 & 0.523 & 0.501 \\
\hline AR2 test (p-value) & 0.375 & 0.271 & 0.212 & 0.312 & 0.199 & 0.271 & 0.210 & 0.230 \\
\hline \multicolumn{9}{|l|}{ Marginal effects } \\
\hline$\alpha_{0}+\alpha_{1}$ & $0.005 * *$ & $-0.003^{* *}$ & $2.057 * *$ & $5.841 * *$ & $0.004 * *$ & $-0.002 * *$ & $2.139 * *$ & $4.082 * *$ \\
\hline$\alpha_{0}+\alpha_{2}$ & $0.006 * *$ & $-0.004 * *$ & $2.998 * *$ & $6.159 * * *$ & $0.005 * *$ & $-0.003 * *$ & $2.697 * *$ & $5.342 * *$ \\
\hline$\alpha_{0}+\alpha_{3}$ & $0.004 * *$ & 0.001 & $1.242 *$ & $4.080 *$ & $0.003^{*}$ & -0.001 & 0.286 & $3.022 *$ \\
\hline$\alpha_{0}+\alpha_{4}$ & $0.003 * *$ & $0.004 * *$ & -0.345 & $-8.882^{* *}$ & 0.001 & $0.001 *$ & 0.240 & $-7.590 * *$ \\
\hline$\alpha_{0}+\alpha_{5}$ & $0.003 *$ & $0.004 * *$ & -0.354 & $-8.972 * *$ & 0.002 & $0.002 *$ & -0.096 & $-7.091 * *$ \\
\hline$\alpha_{0}+\alpha_{1}+\alpha_{2}+\alpha_{3}+\alpha_{4}+\alpha_{5}$ & $0.009 * *$ & $-0.010 * *$ & $5.410 * *$ & $14.070 * *$ & $0.007 * *$ & $-0.007 * *$ & $5.566 * *$ & $12.481 * *$ \\
\hline
\end{tabular}




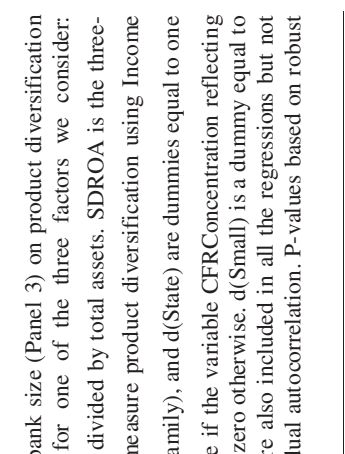

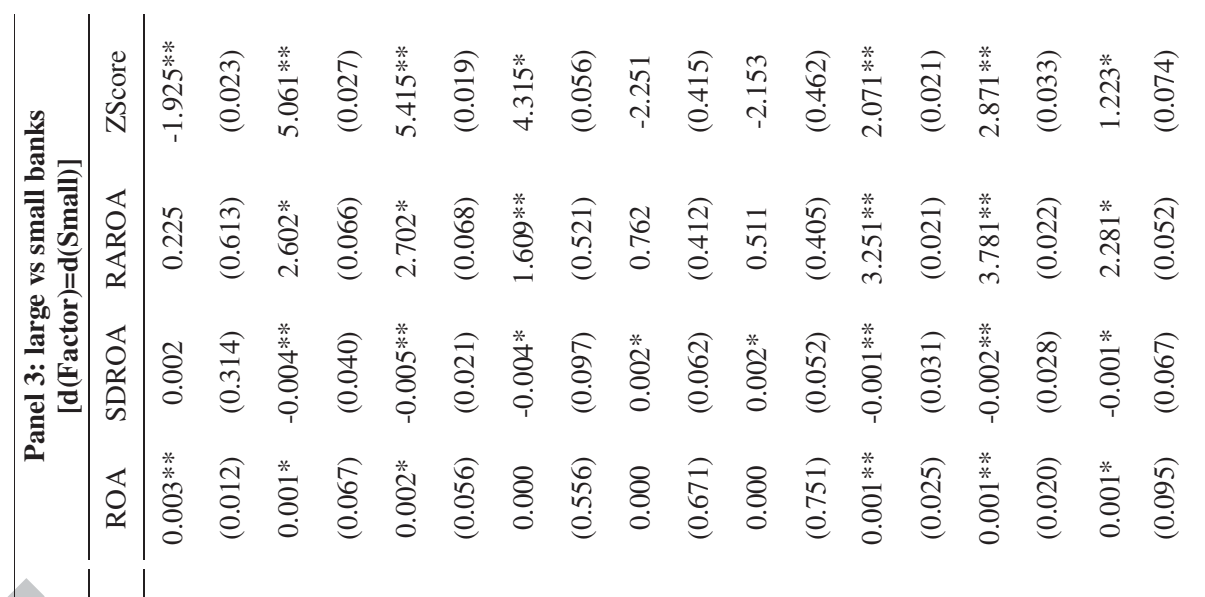

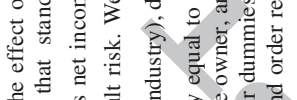

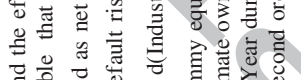

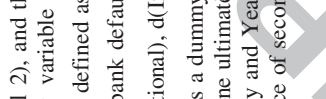

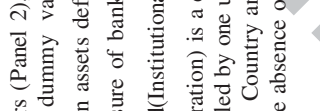

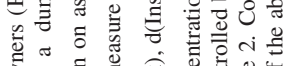

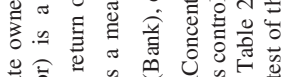

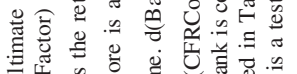

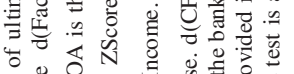

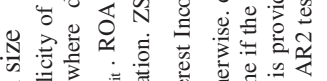

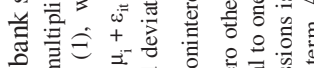

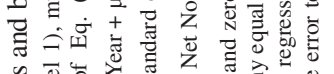

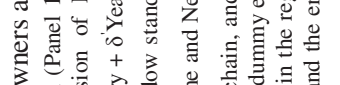

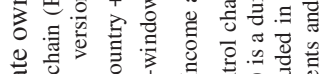

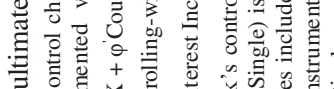

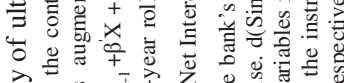

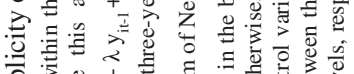

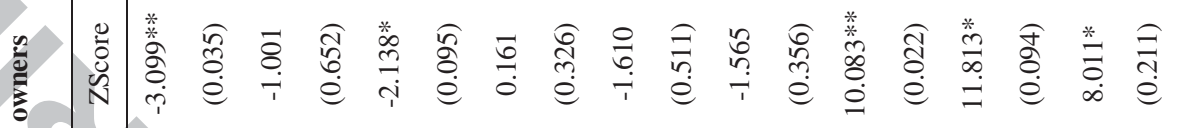

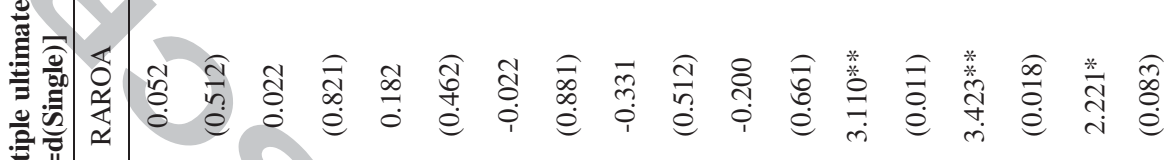

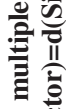

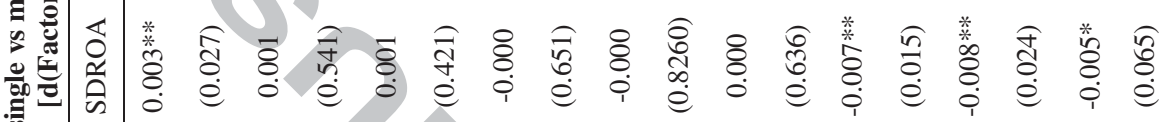

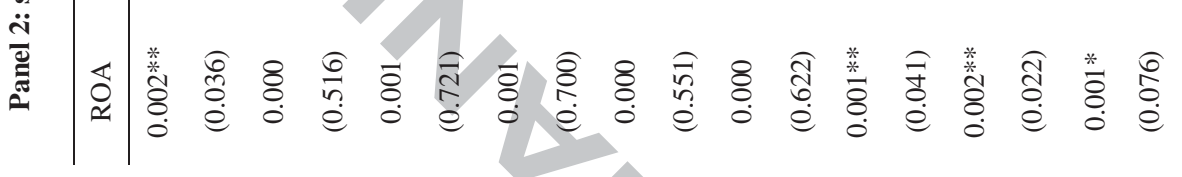

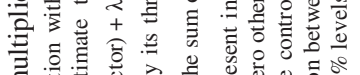

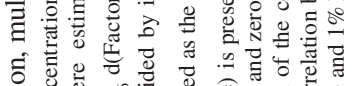

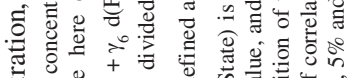

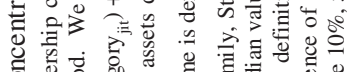

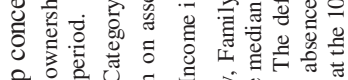

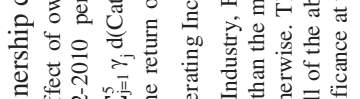

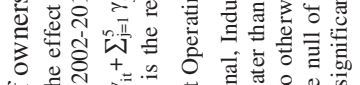

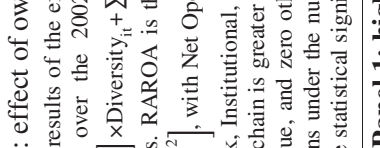

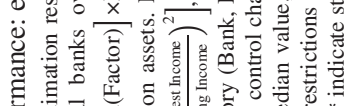

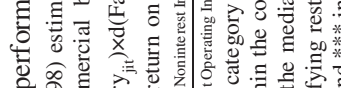
응.

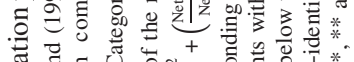

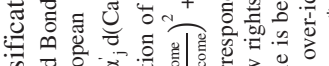

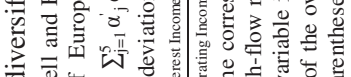

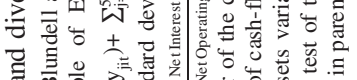

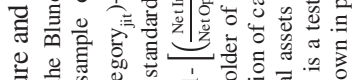

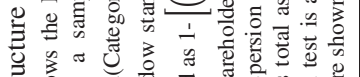

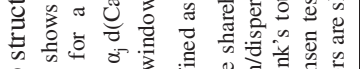

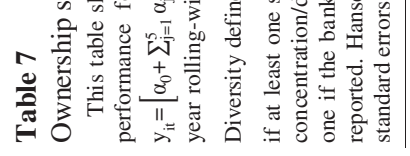

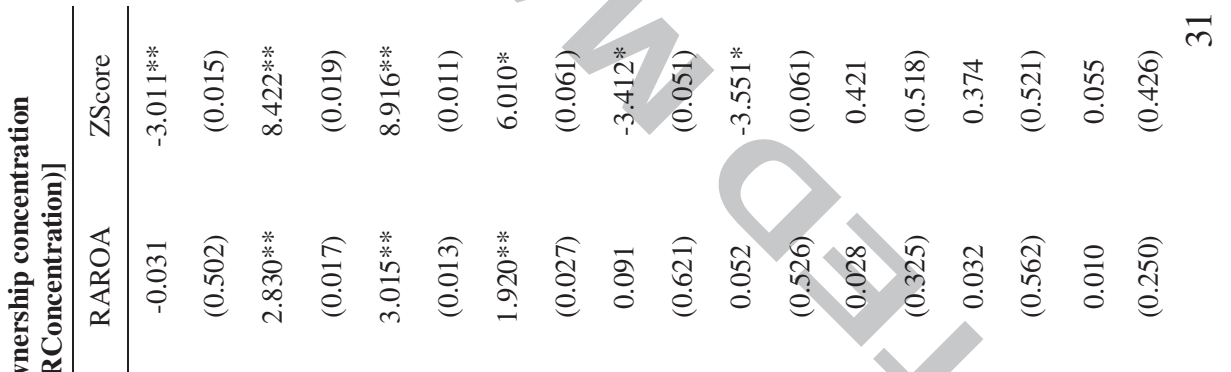




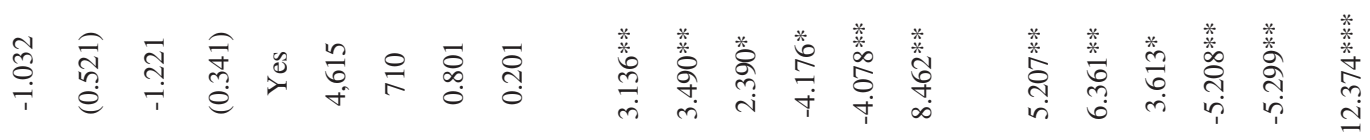

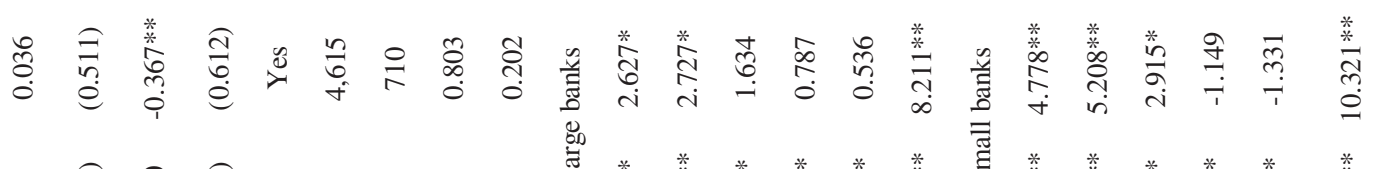

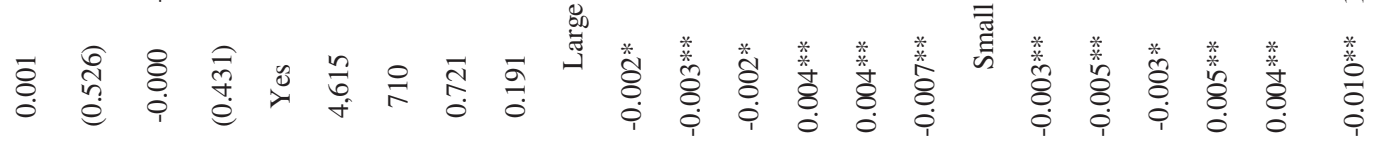

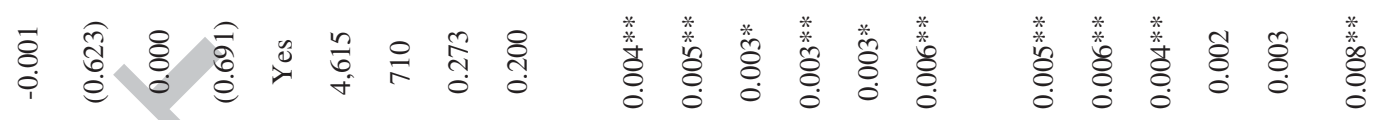

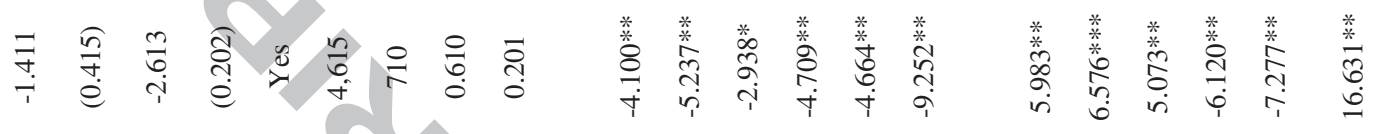

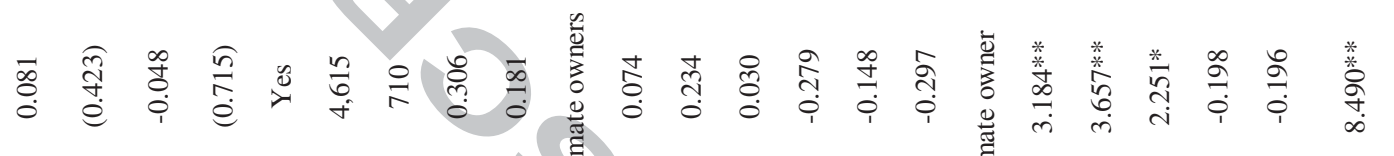

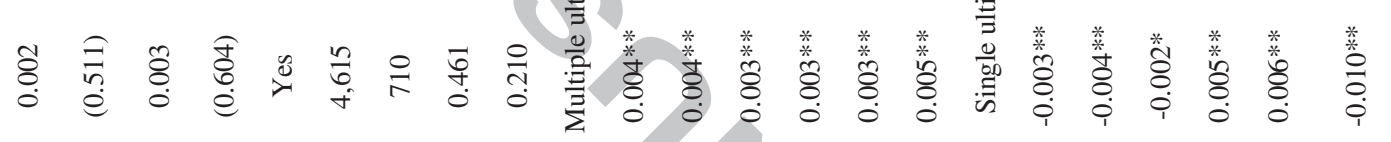

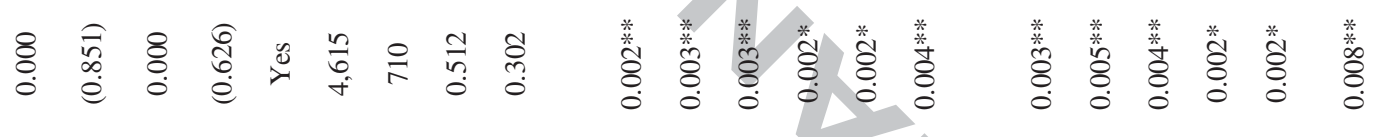

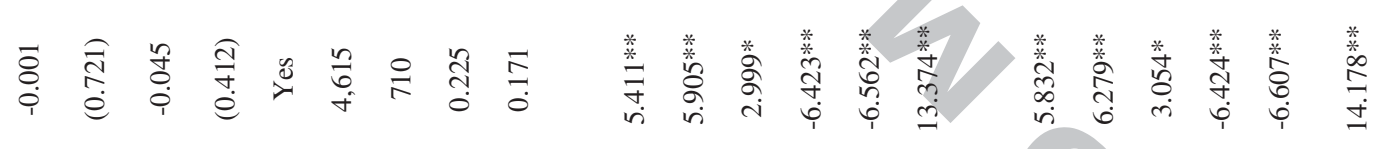

ก

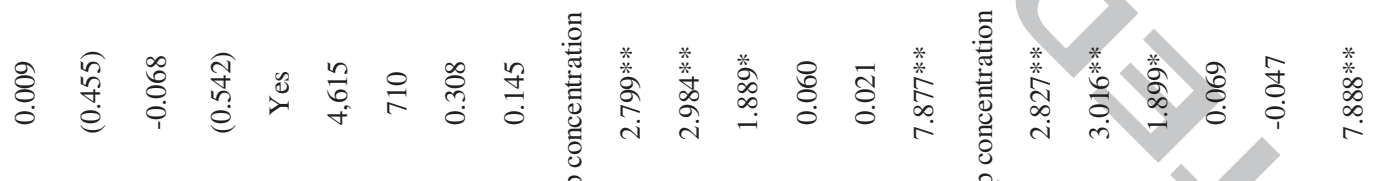

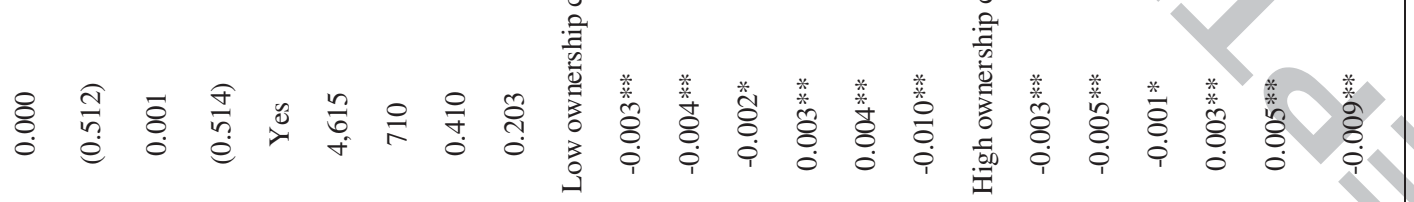

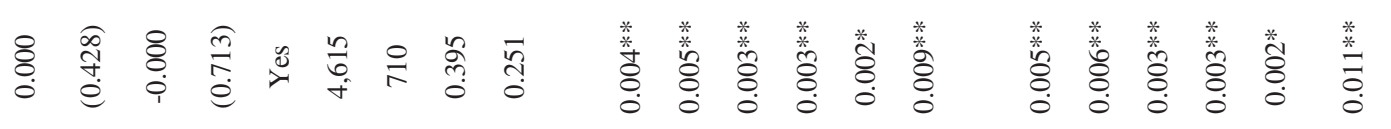

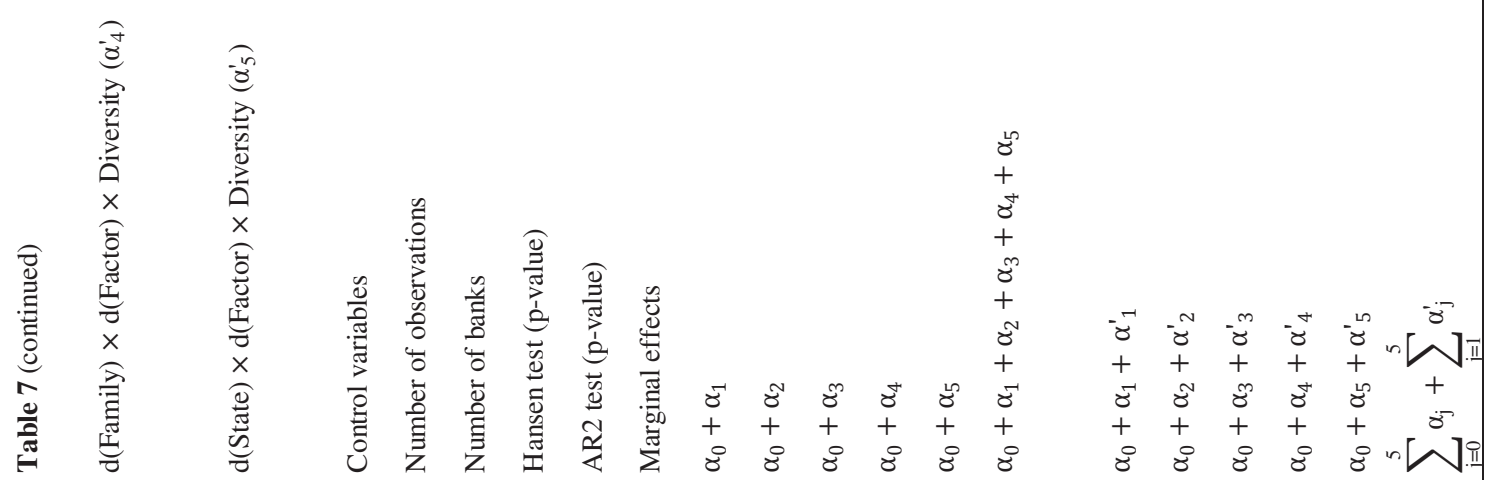




\section{Table 8}

Ownership structure and diversification performance: effect of foreign ownership and the degree of owners' diversification

This table shows the Blundell and Bond (1998) estimation results of the effect of foreign/domestic ownership (Panel 1) and the effect of the degree of owners' diversification (Panel 2) on product diversification performance for a sample of European commercial banks over the 2002-2010 period. We here estimate this augmented version of Eq. (1), where $\mathrm{d}\left(\right.$ Factor) is a dummy variable that stands for one of the two factors we consider: $\mathrm{y}_{\mathrm{it}}=\left[\alpha_{0}+\sum_{\mathrm{j}=1}^{5} \alpha_{\mathrm{j}} \mathrm{d}\left(\right.\right.$ Category $\left._{\mathrm{jit}}\right)+\sum_{\mathrm{j}=1}^{3} \alpha_{\mathrm{j}}^{\prime} \mathrm{d}\left(\right.$ Category $\left._{\mathrm{jit}}\right) \times \mathrm{d}\left(\right.$ Factor $\left.\left._{\mathrm{j}}\right)\right] \times$ Diversity $_{\mathrm{it}}+\sum_{\mathrm{j}=1}^{5} \gamma_{\mathrm{j}} \mathrm{d}\left(\right.$ Category $\left._{\mathrm{jit}}\right)+\sum_{\mathrm{j}=1}^{3} \theta_{\mathrm{j}} \mathrm{d}\left(\right.$ Factor $\left._{\mathrm{j}}\right)+\lambda \mathrm{y}_{\mathrm{it}-1}+\beta^{\prime} \mathrm{X}+\varphi$ 'Country $+\delta^{\prime}$ Year $+\mu_{\mathrm{i}}+\varepsilon_{\mathrm{it}}$. ROA is the return on assets defined as net income divided by total assets. SDROA is the three-year rolling-window standard deviation of the return on assets. RAROA is the return on assets divided by its three-year rolling-window standard deviation. ZScore is a measure of bank default risk. We measure product diversification using Income Diversity defined as 1- $\left[\left(\frac{\text { Net Interest Income }}{\text { Net Operating Income }}\right)^{2}+\left(\frac{\text { Net Noninterest Income }}{\text { Net Operating Income }}\right)^{2}\right]$, with Net Operating Income is defined as the sum of Net Interest Income and Net Noninterest Income. d(Bank), d(Institutional), and d(Industry) are dummies equal to one if at least one shareholder of the corresponding category (Bank, Institutional, Industry) is present in the bank's control chain, and zero otherwise. In Panel 1, d(Factor) stands to the dummy variable $\mathrm{d}\left(\right.$ Domestic $\left._{\mathrm{j}}\right)$ which takes a value of one if at least one shareholder of the category $\mathrm{j}$ is domestic, and zero otherwise. In Panel 2, $\mathrm{d}($ Factor) refers to the dummy variable $\mathrm{d}($ ListedOwner $)$ which takes a value of one if at least one shareholder of the category $\mathrm{j}$ is publicly-listed, and zero otherwise. The definition of the control variables is provided in Table 2. Country and Year dummies are also included in all the regressions but not reported. Hansen test is a test of the over-identifying restrictions under the null of the absence of correlation between the instruments and the error term. AR2 test is a test of the absence of second order residual autocorrelation. P-values based on robust standard errors are shown in parentheses. *,** and *** indicate statistical significance at the $10 \%, 5 \%$ and $1 \%$ levels, respectively.

\begin{tabular}{|c|c|c|c|c|c|c|c|c|}
\hline \multirow[b]{2}{*}{ Dependent variable } & \multicolumn{4}{|c|}{ Panel 1: foreign vs domestic owners } & \multicolumn{4}{|c|}{ Panel 2: privately-owned vs publicly-listed owners } \\
\hline & ROA & SDROA & RAROA & ZScore & ROA & SDROA & RAROA & ZScore \\
\hline \multirow[t]{2}{*}{ Diversity $\left(\alpha_{0}\right)$} & $0.002 * *$ & $0.003 * *$ & 0.101 & $-2.011 * *$ & $0.003 * *$ & $0.002 * *$ & 0.107 & $-2.010 * *$ \\
\hline & $(0.012)$ & $(0.026)$ & $(0.612)$ & $(0.025)$ & $(0.012)$ & $(0.026)$ & $(0.231)$ & $(0.027)$ \\
\hline \multirow{2}{*}{$\mathrm{d}($ Bank $) \times$ Diversity $\left(\alpha_{1}\right)$} & $0.001 * *$ & $-0.003 *$ & $2.461 * *$ & $4.609 * *$ & $0.001 *$ & $-0.004 * *$ & $2.045 * *$ & $4.620 * *$ \\
\hline & $(0.032)$ & $(0.058)$ & $(0.022)$ & $(0.033)$ & $(0.061)$ & $(0.023)$ & $(0.036)$ & $(0.031)$ \\
\hline \multirow[t]{2}{*}{$\mathrm{d}($ Institutional $) \times$ Diversity $\left(\alpha_{2}\right)$} & $0.002 * *$ & $-0.002 * *$ & $3.099 * *$ & $5.131 * *$ & $0.001 * *$ & $-0.005 * *$ & $2.605 * *$ & $4.826 * *$ \\
\hline & $(0.024)$ & $(0.041)$ & $(0.040)$ & $(0.021)$ & $(0.026)$ & $(0.012)$ & $(0.031)$ & $(0.022)$ \\
\hline \multirow{2}{*}{$\mathrm{d}($ Industry $) \times$ Diversity $\left(\alpha_{3}\right)$} & 0.000 & $-0.001 *$ & $1.733 * *$ & $4.406 *$ & 0.001 & $-0.003 *$ & $1.891 * *$ & $3.263^{*}$ \\
\hline & $(0.362)$ & $(0.061)$ & $(0.031)$ & $(0.065)$ & $(0.185)$ & $(0.066)$ & $(0.042)$ & $(0.071)$ \\
\hline \multirow[t]{2}{*}{$\mathrm{d}($ Bank $) \times \mathrm{d}($ Factor $) \times$ Diversity $\left(\alpha_{1}^{\prime}\right)$} & $0.002 * *$ & $-0.002 *$ & $0.788 * *$ & $1.991 * *$ & $0.002 * *$ & $-0.001 * *$ & $1.072 * *$ & $1.683 * *$ \\
\hline & $(0.027)$ & $(0.055)$ & $(0.043)$ & $(0.015)$ & $(0.043)$ & $(0.042)$ & $(0.036)$ & $(0.014)$ \\
\hline \multirow{2}{*}{$\mathrm{d}($ Institutional $) \times \mathrm{d}$ (Factor $) \times$ Diversity $\left(\alpha_{2}^{\prime}\right)$} & $0.002 * *$ & $-0.003 * *$ & $0.895 * *$ & $2.019 * *$ & $0.002 * *$ & $-0.002 * *$ & $1.210 * *$ & $2.061 * *$ \\
\hline & $(0.011)$ & $(0.034)$ & $(0.020)$ & $(0.021)$ & $(0.021)$ & $(0.011)$ & $(0.021)$ & $(0.015)$ \\
\hline \multirow[t]{2}{*}{$\mathrm{d}($ Industry $) \times \mathrm{d}$ (Factor $) \times$ Diversity $\left(\alpha_{3}^{\prime}\right)$} & $0.001^{*}$ & $-0.003 * *$ & $0.633 *$ & $0.801 *$ & $0.001 *$ & $-0.001 *$ & $0.605^{*}$ & $1.101^{*}$ \\
\hline & $(0.062)$ & $(0.044)$ & $(0.071)$ & $(0.081)$ & $(0.067)$ & $(0.063)$ & $(0.055)$ & $(0.061)$ \\
\hline Control variables & Yes & Yes & Yes & Yes & Yes & Yes & Yes & Yes \\
\hline Number of observations & 4,615 & 4,615 & 4,615 & 4,615 & 4,615 & 4,615 & 4,615 & 4,615 \\
\hline Number of banks & 710 & 710 & 710 & 710 & 710 & 710 & 710 & 710 \\
\hline Hansen test ( $\mathrm{p}$-value) & 0.281 & 0.417 & 0.522 & 0.750 & 0.213 & 0.413 & 0.425 & 0.525 \\
\hline AR2 test (p-value) & 0.412 & 0.228 & 0.201 & 0.210 & 0.304 & 0.211 & 0.209 & 0.211 \\
\hline Marginal effects & \multicolumn{4}{|c|}{ Foreign owners } & \multicolumn{4}{|c|}{ Privately-owned owners } \\
\hline$\alpha_{0}+\alpha_{1}$ & $0.003 * *$ & 0.000 & $2.562 * *$ & $2.598 * *$ & $0.004 * *$ & $-0.002 *$ & $2.152 *$ & $2.610^{*}$ \\
\hline$\alpha_{0}+\alpha_{2}$ & $0.004 * *$ & 0.001 & $3.200 * *$ & $3.120 * *$ & $0.004 * *$ & $-0.003 * *$ & $2.712^{* *}$ & $2.816^{*}$ \\
\hline$\alpha_{0}+\alpha_{3}$ & $0.002 *$ & 0.002 & 1.834 & $2.395 * *$ & $0.004 * *$ & $-0.001 *$ & $1.998 *$ & 1.253 \\
\hline \multirow[t]{2}{*}{$\alpha_{0}+\alpha_{1}+\alpha_{2}+\alpha_{3}$} & $0.005 * *$ & $-0.003^{*}$ & $7.394 * *$ & $12.135^{* * *}$ & $0.006 * *$ & $-0.010 * * *$ & $6.648 * *$ & $10.699 * * *$ \\
\hline & \multicolumn{4}{|c|}{ Domestic owners } & \multicolumn{4}{|c|}{ Publicly-listed owners } \\
\hline$\alpha_{0}+\alpha_{1}+\alpha_{1}^{\prime}$ & $0.005 * *$ & $-0.002 * *$ & $3.350 * *$ & $4.589 * *$ & $0.006 * *$ & $-0.003 * *$ & $3.224 * *$ & $4.293 * *$ \\
\hline$\alpha_{0}+\alpha_{2}+\alpha_{2}^{\prime}$ & $0.006^{* *}$ & $-0.002 * *$ & $4.095^{* *}$ & $5.139 * *$ & $0.006 * *$ & $-0.005 * *$ & $3.922 * *$ & $4.877 * *$ \\
\hline \multirow{3}{*}{$\begin{array}{l}\alpha_{0}+\alpha_{3}+\alpha_{3}^{\prime} \\
\sum^{3} \alpha_{j}+\sum^{3} \alpha_{j}^{\prime}\end{array}$} & $0.003 * *$ & $-0.001 *$ & $2.467 * *$ & $3.196 * *$ & $0.005 * *$ & $-0.002 *$ & $2.603 *$ & $2.354 *$ \\
\hline & & & & & & & & \\
\hline & $0.010 * *$ & $-0.011 * *$ & $9.710 * *$ & $16.946 * *$ & $0.011 * *$ & $-0.014 * *$ & $9.535^{* * *}$ & $15.544 * * *$ \\
\hline
\end{tabular}

